\title{
Carbon dynamics in a Boreal land-stream-lake continuum during the spring freshet of two hydrologically contrasting years
}

\author{
H. Miettinen $(\mathbb{D} \cdot$ J. Pumpanen $(\mathbb{D}) \cdot$ M. Rantakari $(\mathbb{D} \cdot$ A. Ojala $\mathbb{C}$
}

Received: 4 July 2019/Accepted: 13 February 2020/Published online: 27 February 2020

(C) The Author(s) 2020

\begin{abstract}
We studied in 2013 and 2014 the spring carbon dynamics in a Boreal landscape consisting of a lake and 15 inflowing streams and an outlet. The first year had weather and a hydrological regime typical of past years with a distinct spring freshet connected with the thaw of the average snowpack. The latter year had
\end{abstract}

Responsible Editor: Melany Fisk.

Electronic supplementary material The online version of this article (https://doi.org/10.1007/s10533-020-00648-9) contains supplementary material, which is available to authorized users.

H. Miettinen

Faculty of Biological and Environmental Sciences, University of Helsinki, P.O. Box 65, 00014 Helsinki, Finland

Present Address:

H. Miettinen $(\triangle)$

Department of Forest Ecology and Management, Swedish University of Agricultural Sciences, Skogsmarksgränd 17, 90183 Umeå, Sweden

e-mail: heli.miettinen@slu.se

\section{J. Pumpanen}

Department of Environmental and Biological Sciences, University of Eastern Finland, P.O. Box 1627,

70211 Kuopio, Finland

M. Rantakari

Urban Environment Division, Environment Protection Unit, City of Helsinki, P.O. Box 58235, 00099 Helsinki, Finland higher air temperatures which did not permit snow accumulation, despite similar winter precipitation. As such, there was hardly any spring freshet in 2014, and stream discharge peaked in January, i.e., the conditions resembled those predicted in the future climate. Despite the hydrological differences between the years, there were only small interannual differences in the stream $\mathrm{CO}_{2}$ and DOC concentrations. The relationship between the concentrations and discharge was stronger in the typical year. $\mathrm{CO}_{2}$ concentrations in medium-sized streams correlated negatively with the discharge, indicating dilution effect of melting

\footnotetext{
A. Ojala

Faculty of Biological and Environmental Sciences, Ecosystems and Environment Research Programme, University of Helsinki, Niemenkatu 73, 15140 Lahti, Finland
}

\section{A. Ojala}

Institute for Atmospheric and Earth System Research/ Physics, Faculty of Science, University of Helsinki, P.O. Box 68, 00014 Helsinki, Finland

\section{A. Ojala}

Faculty of Agriculture and Forestry, Institute for Atmospheric and Earth System Research/Forest Sciences, University of Helsinki, P.O. Box 27, 00014 Helsinki, Finland 
snowpacks, while in large-sized streams the correlation was positive, suggesting stronger groundwater influence. The DOC pathway to these streams was through the subsurface soil layers, not the groundwater. The total amount of carbon transported into the lake was $c a$. 1.5-fold higher in the typical year than in the year with warm winter. In 2013, most of the lateral inputs took place during spring freshet. In 2014, the majority of inputs occurred earlier, during the winter months. The lateral $\mathrm{CO}_{2}$ signal was visible in the lake at $1.5 \mathrm{~m}$ depth. DOC dominated the carbon transport, and in both years, $12 \%$ of the input $\mathrm{C}$ was in inorganic form.

Keywords $\mathrm{CO}_{2} \cdot \mathrm{DOC} \cdot$ Lake carbon dynamics . Temporality $\cdot$ Terrestrial carbon export

\section{Introduction}

Inland waters, such as streams, rivers, and lakes play an essential role in the carbon (C) cycle at the catchment as well as the global scale (Aufdenkampe et al. 2011; Battin et al. 2009; Cole et al. 2007). There are still significant uncertainties in temporal eventbased export of terrestrial $\mathrm{C}$ into the freshwaters (Drake et al. 2018), with the timing of events being important at both the local (Dinsmore \& Billett 2008) and the regional (Zarnetske et al. 2018) scale. Aquatic ecosystems connect hydrologically to terrestrial ecosystems, and terrestrially fixed $\mathrm{C}$ transported to lakes is processed therein, becoming deposited into the sediments and released to the atmosphere in gaseous form (Battin et al. 2009). This transport and release of $\mathrm{C}$ is particularly important in the Boreal region, where water bodies are abundant and cover a substantial part of the landscape (Verpoorter et al. 2014). Surface waters, i.e. streams or overland flow, transport a significant amount of terrestrial $\mathrm{C}$ from the catchment areas to lakes, which can result in a 6-50\% decrease of net ecosystem exchange in forested and peatland catchments, respectively (Dinsmore et al. 2010; Huotari et al. 2011; Jonsson et al. 2007; Rasilo 2013). Further, organic $\mathrm{C}$ of terrestrial origin contributes to $30-80 \%$ of the $\mathrm{C}$ released from lakes to the atmosphere (Algesten et al. 2003; Jonsson et al. 2007).

Laterally transported carbon in streams consist of total organic carbon (TOC) and dissolved inorganic carbon (DIC). The most important dissolved forms of carbon are methane $\left(\mathrm{CH}_{4}\right)$ and carbon dioxide $\left(\mathrm{CO}_{2}\right)$. Further, TOC is categorized into dissolved organic carbon (DOC) and particulate organic carbon (POC). Most of the laterally transported carbon is in organic form and dissolved in water and thus, the DOC is among the most studied $\mathrm{C}$ species (e.g., Rasilo et al. 2015; Wallin et al. 2015), while the amounts of POC is often insignificant (Laudon et al. 2004; Leach et al. 2016). Besides the organic $C$ inputs, lakes also receive inorganic C (DIC) originating mainly from soil respiration processes and from the weathering reactions (Campeau et al. 2017). The importance of DIC in total C transport is clearly smaller, e.g., in Boreal peatland catchment it contributed up to $33 \%$ of total annual transport (Leach et al. 2016). However, the contribution of DIC may be higher in catchments with smaller peatland coverage (Huotari et al. 2013). In streams with low temperature and $\mathrm{pH}$ conditions, typical of the Boreal streams, most of the DIC is in form of free carbon dioxide $\left(\mathrm{CO}_{2}\right)$. The inorganic $\mathrm{C}$ has a direct but shorter-lasting influence on lacustrine $\mathrm{C}$ dynamics than the organic $\mathrm{C}$ inputs (e.g. Rasilo et al. 2011), and due to its smaller contribution to aquatic exports it is also less studied. Lateral and atmospheric fluxes of $\mathrm{CH}_{4}$ have a small role in carbon cycle in the Boreal catchments, consisting less than $5 \%$ of the total export (Dinsmore et al. 2010; Leach et al. 2016; Miettinen et al. 2015). However, although the downstream $\mathrm{C}$ transport to lakes is widely acknowledged, there are only a few comprehensive studies on the horizontal mixing of external $\mathrm{C}$ inputs and its influence into the lake C dynamics (Cortés et al. 2017; Denfeld et al. 2018; Pasche et al. 2019; Vachon et al. 2017).

Riparian zones are usually rich in organic matter (OM) and are one of the most active sites of $\mathrm{C}$ exchange (Bishop et al. 1994; Grabs et al. 2012). Due to vigorous transformation, transportation and retention of OM they can be referred to as ecosystems control points (Bernhardt et al. 2017) where hydrology is of utmost importance for the connectivity with stream channels (Ledesma et al. 2018; Leith et al. 2015; Lyon et al. 2011). The riparian soil influence on the $\mathrm{C}$ concentrations and fluxes is most substantial in headwaters (Kling et al. 2000; Teodoru et al. 2009), in contrast, for large, higher order rivers the physical characteristics such as discharge mediate the soil inputs (Teodoru et al. 2009). In the Boreal region, the 
hydrology during winter and spring periods is controlled by precipitation, which mainly falls in form of snow and accumulates in the snowpack. The thawing of snow in spring results in flooding (Korhonen \& Kuusisto 2010), which has multifaceted effects on terrestrial $\mathrm{C}$ transport towards streams and lakes. Flooding mobilizes the soil $\mathrm{C}$ by saturating the soil pores from below and raises the level of groundwater (Nyberg et al. 2001), which is rich in $\mathrm{CO}_{2}$ and TOC (Grabs et al. 2012; Leith et al. 2015). This highly C concentrated soil water (i.e. shallow groundwater input) enters into the stream through the riparian zones and is transported forward along the stream channels. However, melting snow packs can also release water low in $\mathrm{C}$, which results in decrease in concentrations due to dilution effect in stream channels (Dyson et al. 2011). For Boreal ecosystems, the spring freshet is usually considered the most critical hydrological event transporting terrestrial $\mathrm{C}$ to the aquatic environments and can be responsible for more than half of the annual $\mathrm{C}$ transport of $\mathrm{CO}_{2}$ (Dinsmore et al. 2013a), and organic C (DOC, TOC) (Laudon et al. 2004; Striegl et al. 2001).

Transport of terrestrially fixed $\mathrm{C}$ is very sensitive to precipitation changes both annually and seasonally. Annually DOC concentrations and export from the terrestrial upland catchment via soil water runoff are mainly influenced by precipitation, while other physical environmental factors behind the DOC formation in soils, e.g., soil temperature, are also important (Pumpanen et al. 2014). Events of high precipitation increase the amount of terrestrial $\mathrm{C}$ in streams and lakes, but the time lag between the event and the concentration increase can vary (Dinsmore and Billett 2008; Ojala et al. 2011; Rasilo et al. 2011). For instance, Rantakari and Kortelainen (2005) observed in that in Boreal catchments summer and autumn precipitation rapidly increased the terrestrial $\mathrm{C}$ export to lakes, whereas lacustrine $\mathrm{CO}_{2}$ release remained unaffected till the following spring (Rantakari and Kortelainen 2005). On the other hand, Ojala et al. (2011) recorded higher atmospheric $\mathrm{CO}_{2}$ fluxes in lakes soon after the long-lasting summer rains, which were responsible for $46 \%$ of the total annual atmospheric $\mathrm{CO}_{2}$ release due to the enhanced transport of external C from the catchment (Ojala et al. 2011).

In the future, the Boreal zone is predicted to have higher winter floods and smaller spring freshets due to warmer temperatures and more frequent rains and decreased snow accumulation in winter (IPCC 2013; Veijalainen et al. 2010). However, the influence of snow cover changes to lateral $\mathrm{C}$ transport is poorly understood. Model simulations show that decrease in snow cover depth may increase soil temperatures especially in spring which suggest earlier snowmelt (Jungqvist et al. 2014). On the other hand, decrease in snow cover increase the soil frost, which is found to increase the soil DOC concentrations (Haei et al. 2010). So far, for instance, in Finland, there have been no signs of a change in magnitude of the spring freshets, but since 1912 they have come on average 8 days earlier per decade (Korhonen \& Kuusisto 2010).

$\mathrm{C}$ dynamics in ice-covered lakes have lately raised more interest among researchers, and now its dynamic character is appropriately considered (Denfeld et al. 2018; Karlsson et al. 2013; MacIntyre et al. 2018). Ice cover period in Boreal lakes, lasting for several months, blocks the gas exchange between water surfaces and the atmosphere resulting in $\mathrm{C}$ gas accumulation under the ice cover (e.g. Huotari et al. 2009; Karlsson et al. 2013). $\mathrm{C}$ gas accumulation, as well as $\mathrm{C}$ dynamics in lakes, depends on a multitude of processes: in-lake metabolism such as primary production (Baehr and DeGrandpre 2004; Striegl et al. 2001), mineralization of organic matter (OM) (Vachon et al. 2016), quantity and quality of allochthonous inputs both before and during the ice cover period (Cortés et al. 2017; Denfeld et al. 2015; Striegl et al. 2001) and additionally physical and chemical conditions such as water movements and hypoxia/anoxia (e.g. Kirillin et al. 2012). In comparison to traditional discrete samplings, continuous measurement techniques provide better information on the gas concentrations and consequent atmospheric fluxes more typically capturing the ice thaw period, which makes it possible to evaluate the influence of hydrological spring event in streams on $\mathrm{C}$ dynamics in the receiving lakes. To date, the lateral fresh $\mathrm{CO}_{2}$ inputs during ice thaw period has mostly been ignored in studies of $\mathrm{C}$ dynamics at the ice-melt. To understand how changes in snow accumulation and melt in the future are likely to impact carbon export across the Boreal region, we need to deepen the understanding about the connection between lentic and lotic systems during the snowmelt period.

In this study, we combined automatic and discrete measurements to estimate the total lateral transport of carbon dioxide $\left(\mathrm{CO}_{2}\right)$ and dissolved organic carbon (DOC) in small headwater streams draining to and 
from a Boreal lake. The particular interest of these $\mathrm{C}$ species was based on the importance of $\mathrm{CO}_{2}$ in cold waters with low $\mathrm{pH}$ at high latitudes and the abundance of DOC in surface waters comprising most of the laterally transported carbon. We compared the lateral inputs of $\mathrm{CO}_{2}$ with the less studied dynamics of $\mathrm{CO}_{2}$ in the lake water column during two hydrologically different years from ice-on until the end of May in 2013 and 2014. The former represents a typical year with a substantial hydrological spring freshet and the latter a year with a weak spring flood after a warm winter; the latter thus resembles the model predictions on climate change, i.e., decreased spring flooding due to decrease in snowfall and snow accumulation due to higher winter temperatures (IPCC 2013; Veijalainen et al. 2010). We hypothesized that the concentrations of $\mathrm{CO}_{2}$ and DOC in streams are higher after a warmer than a typical winter, due to less dilution from the thawing snow packs (with low concentrations) and stronger influence of the shallow groundwater sources (with high concentrations). Furthermore, we assumed that there would be differences in timing and amount of lateral input through the streams into and from the lake between years with the same precipitation sum, but different snow accumulation and melt pattern. Further, we analyzed the concentration gradients of $\mathrm{CO}_{2}$ in the lake and hypothesized, that the drainage and shallow groundwater flow during a warm winter increases the concentrations gradually keeping them high during the ice cover period whereas during the typical winter there are less inputs during ice cover period due to ice and snow accumulation, and the $\mathrm{C}$ inputs will mainly occur after snowmelt and increase the concentrations in the lake rapidly. Finally, we evaluated the impacts of the spring freshet on the lateral $\mathrm{C}$ transport, for a Boreal catchment, in the entirety consisting of 15 small streams and a lake with its outlet. Our results provided new insight into the coupling of Boreal streams and a lake ecosystem at the most important time of the annual $\mathrm{C}$ cycling.

\section{Materials and methods}

Study site

The study area, Lake Kuivajärvi, and its catchment area, are situated in southern Finland near the SMEAR II -station (Station for Measuring Ecosystem-
Atmosphere Relations; $61^{\circ} 51^{\prime} \mathrm{N}, 24^{\circ} 17^{\prime} \mathrm{E}, 180$ a.s.l) and Hyytiälä Forestry Field Station of the University of Helsinki (Fig. 1). The catchment area of the lake is 914 ha in size (of which 71 ha covered by lakes) and consists mainly of Scots pine (Pinus sylvestris L.) and Norway spruce (Picea abies (L.) Karst.) dominated managed forests and small amounts of peatlands and agricultural land (Miettinen et al. 2015). The 30-year annual mean temperature and precipitation are $3.5{ }^{\circ} \mathrm{C}$ and $711 \mathrm{~mm}$, respectively (Pirinen et al. 2012). Lake Kuivajärvi is a small (63.8 ha), unregulated Boreal lake. It is narrow and oblong with a length of $2.6 \mathrm{~km}$ and a mean depth of $6.4 \mathrm{~m}$. The length of its shoreline is $6.1 \mathrm{~km}$. It is humic and mesotrophic lake (Miettinen et al. 2015). In this dimitic lake the ice cover period typically lasts for five months (from late November to early May).

During the spring freshet, 15 streams are draining to Lake Kuivajärvi (Fig. 1). Most of these are shallow and ephemeral; besides the spring freshet, they only appear after very heavy rains. The main inlet Saarijärvenpuro (S5) in the north end of the lake with the highest discharge connects lakes Kuivajärvi and Saarijärvi (15.3 ha) and flows all year round. Two of the secondary inlets (S3 and S6) in the north end of the lake with considerable discharges flow during the icefree seasons, even though the discharge during lowflow periods can be minimal. The outlet stream Huikonjoki drains the lake in the south, and thus, most of the incoming water flows through the whole lake. The lake water residence time is 439 days (3year mean; 2011-2013).

Sampling and measurements

\section{Streams}

The sampling took place in streams, and in the lake in December 2012-May 2014, and the measurements covered the ice cover period, the spring freshet, the ice-out in the lake and continued as an open water period at least one month after the ice-out. In the secondary inlets, the sampling was carried out weekly after 18 April in 2013 and 25 March in 2014 when the flow was detectable, which was also defined as the onset of the spring freshet. The end of the freshet period was the complete ice-off in the lake. The measurements were carried out until the end of May. The main inlet and outlet were sampled fortnightly 


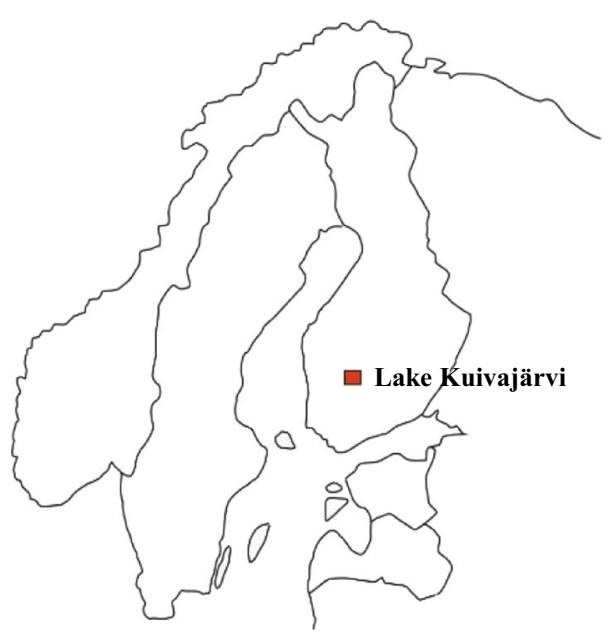

Fig. 1 The location of Lake Kuivajärvi in North Europe. The bathymetric map of Lake Kuivajärvi and the inlet streams (S1S15) and the outlet stream around the lake. The different colors

from the beginning of December, and when the freshet period started, they were sampled weekly, too. Samples from the free-flowing stream water were taken from the surface $(2 \mathrm{~cm}$ depth) as close to the stream mouth as possible. Two replicate gas samples were taken into $60 \mathrm{ml}$ plastic syringes to analyze dissolved $\mathrm{CO}_{2}$ concentrations in water. Besides, another water sample for DOC was taken. Water temperature was measured in situ during the sampling.

To estimate the total riverine $\mathrm{C}$ input into the lake and output from the lake, we measured the water discharge at the same time with DOC and $\mathrm{CO}_{2}$ sampling weekly in the flowing secondary streams with an acoustic flow meter (SonTek FlowTracker Handheld ADV®, SonTek, San Diego, CA, USA) in three different points and used the mean of the measurements for further calculations. In the main inlet and the outlet, the discharge was measured over 14-weeks period in 2012 and 2013 and it covered the times of the high flows as well as the base flows periods. The discharge was measured with an acoustic flow meter (SonTek FlowTracker handheld ADV®, SonTek, San Diego, CA, USA). Water level in these

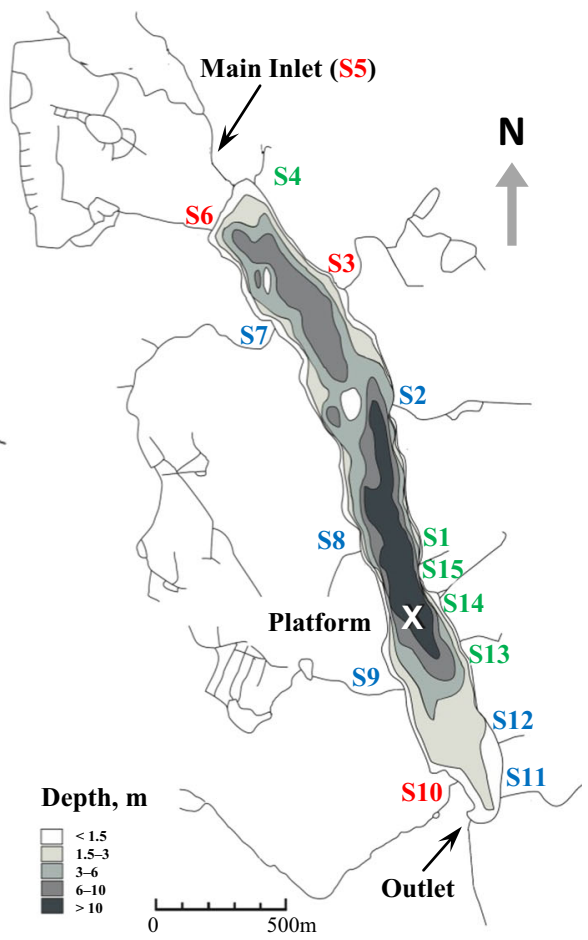

of stream codes represent the streams size groups; green for the small, blue for the medium and red for the large-sized streams

streams was recorded continuously at $30 \mathrm{~min}$ intervals with Levelogger Edge data loggers (Solinst Canada Ltd., Georgetown, Ontario, Canada) submerged in the bottom of the streams and compensated with air pressure measured with a Barologger Gold data logger (Solinst Canada Ltd., Canada). The daily discharge was estimated based on the continuous water level and stream discharge measurements.

Lake

In the lake, we monitored the $\mathrm{CO}_{2}$ concentrations and temperature continuously. Besides, we also performed manual gas sampling fortnightly during the ice cover period, daily during the first week after the ice-out and then once a week until the end of May. DOC sampling took place monthly during the study period. Due to weak ice before the ice-out, the manual measurements had to be interrupted for 15 and 21 days in 2013 and 2014, respectively.

In the lake, a system for continuous measurement of $\mathrm{CO}_{2}$ at the depths of $1.5 \mathrm{~m}, 2.5 \mathrm{~m}$, and $7.0 \mathrm{~m}$, was installed in 2009, when a platform was constructed in 
the middle of the lake (Fig. 1). The measuring system is a closed system for each depth individually, consisting of infrared sensors for measuring $\mathrm{CO}_{2}$ (CARBO-CAP GMP343, Vaisala Oyj, Helsinki, Finland) connected to a 1-m-long semi-permeable silicon rubber tube installed at each measuring depth via stainless steel tubes extending to the measurement depth. The silicon rubber tube allows the exchange of gases between the system and the water in the measurement depth. The air in the system is continuously circulated with a pump (Gardener Denver Thomas GmbH SMG-4, Puchheim, Germany). The sensors were in a temperature-controlled box in the platform. For more detailed information on the measurement setup, see Hari et al. (2008) and Provenzale et al. (2018). The concentrations in the water $\left(\mu \mathrm{mol} \mathrm{L}^{-1}\right)$ were calculated using the temperature dependence of $\mathrm{CO}_{2}$ solubility in water using an appropriate Henry's law constant and the equation from Hari et al. (2008)

$C_{\mathrm{CO}_{2}}=X_{\mathrm{CO}_{2}} P K_{h}$

where $X_{\mathrm{CO}_{2}}$ is the concentration measured with the sensor (ppm), $\mathrm{P}$ is the atmospheric pressure (atm), and $\mathrm{K}_{\mathrm{h}}$ is Henry's law constant with the appropriate temperature in measuring depth. There were gaps in the $\mathrm{CO}_{2}$ data either due to sensors malfunctioning or power cut-offs. Thus, the periods of data outage at each depth were gap-filled with values that were calculated from the linear regression model between the continuous and manual $\mathrm{CO}_{2}$ measurements. To describe the physical conditions in the lake, we used temperature data from continuously logging thermistor string with Pt100 resistance thermometers in 16 different depths $(0.2,0.5,1.0,1.5,2.0,2.5,3.0,3.5$, 4.0, 4.5, 5.0, 6.0, 7.0, 8.0, 10.0 and $12.0 \mathrm{~m}$ ).

The manual samples were taken from the water column with a Limnos ${ }^{\circledR}$ water sampler $\left(2.0 \mathrm{dm}^{3}\right)$. The water samples for DOC were taken from the surface $(0.2 \mathrm{~m})$ and close to the bottom of the lake $(12.0 \mathrm{~m})$. Manual $\mathrm{CO}_{2}$ samples were taken from depths of 1.0, 3.0 , and $7.0 \mathrm{~m}$ into two plastic syringes. The ice thickness and snow depth on the ice were measured near the platform at each sampling occasion. The air temperature and precipitation were obtained from the SMEAR II station next to the study lake. The snow cover depth in the terrain was estimated as a mean of seven different measuring locations in the SMEAR II forest.

\section{Laboratory analyses}

The gas samples from the streams and the lake were processed within less than $2 \mathrm{~h}$ after sampling in the laboratory of Hyytiälä Forestry Field Station with the headspace equilibrium technique (McAuliffe 1971). In the laboratory, $30 \mathrm{~mL}$ of water was pushed out from the syringe and refilled with $\mathrm{N}_{2}$ gas. To equilibrate the water and gas phases in the syringes, they were placed in a water bath at $20{ }^{\circ} \mathrm{C}$ for $30 \mathrm{~min}$ and then shaken vigorously for $3 \mathrm{~min}$. The gas samples collected from the headspace were stored in pre-evacuated $12 \mathrm{~mL}$ Exetainer ${ }^{\circledR}$ vials (Labro Ltd., Lampeter, Ceredigion, UK) by pressurizing the vial and stored in the dark at $4{ }^{\circ} \mathrm{C}$ until analyzed with a gas chromatograph (GC). The GC (Agilent 7890, Agilent Technologies, Palo Alto, CA, USA) was equipped with a flame-ionization detector (FID; $300{ }^{\circ} \mathrm{C}$ ) and a thermal conductivity detector (TDC; $250^{\circ} \mathrm{C}$ ). The mean values from these two detectors were used in final calculations. For more information, see Miettinen et al. (2015). The partial pressure of $\mathrm{CO}_{2}$ was converted to gas concentrations $\left(\mathrm{mg} \mathrm{L}^{-1}\right)$ using Henry's law and the temperature relationship at $20^{\circ} \mathrm{C}$.

The DOC samples were filtered through a $0.45 \mu \mathrm{m}$ membrane filter with a vacuum filtering system (Millipore, Millipore Corporation, Billerica, MA) within a few hours of sampling. The filtered samples were stored in the dark at $-18{ }^{\circ} \mathrm{C}$ and later analyzed with a $\mathrm{C}$ analyzer in the laboratory of Forest Sciences of University of Helsinki (TOC- $\mathrm{V}_{\mathrm{cph}}$, Shimadzu Corporation, Kyoto, Japan).

Lateral flux calculations

For the daily lateral transport of $\mathrm{CO}_{2}$ and $\mathrm{DOC}$, the missing values between the measured concentrations and stream discharge were estimated with linear interpolation. The daily lateral transport was calculated by multiplying the corresponding concentration with the daily discharge into and from the lake. The lateral transport during different periods was obtained by integrating the daily $\mathrm{CO}_{2}$ and DOC transport over the ice cover period, freshet, and open water period.

\section{Data analyses}

For the analysis, we divided the data into three different periods each year; ice cover, freshet, and 
open water period. To compare the $\mathrm{CO}_{2}$ and $\mathrm{DOC}$ concentrations in streams between the years and to figure out the possible differences in $\mathrm{CO}_{2}$ and $\mathrm{DOC}$ concentrations caused by the water flow intensity, the inlet streams were divided into three groups depending on the discharge in 2013; i.e., large streams with a mean discharge $>20 \mathrm{~m}^{3} \mathrm{~s}^{-1}$ (streams S3, S5, S6 and S10), medium-sized streams with discharge $<20$ $\mathrm{m}^{3} \mathrm{~s}^{-1}$ (streams S2, S7, S8, S9, S11 and S12) and small streams (streams S1, S4, S13, S14 and S15), which were present in 2013, but were completely dry in 2014.

All data were log-transformed before the analysis. As the assumption for the normality of data was not fulfilled, the non-parametric Kruskal-Wallis test $(p<0.05)$ was used to determine the differences between years, periods, and stream size groups. We studied the relationship between concentrations of $\mathrm{CO}_{2}$ and DOC and discharge in different years with streams divided into size groups with correlation analysis. For correlations, we used Spearman correlations, because not all the variables fulfilled the assumption of normality. All statistical analyses were performed with IBM SPSS Statistics 21 (IBM Corporation, New York).

\section{Results}

\section{Weather conditions}

In 2013, the daily mean air temperature remained above $0{ }^{\circ} \mathrm{C}$ after the 11 th of April, with no cold spells after that. In the warm winter 2013-2014, the mean air temperatures rose above $0{ }^{\circ} \mathrm{C}$ for the first time already in late December 2013, then varied around $0{ }^{\circ} \mathrm{C}$ resulting in a slowly warming spring (Fig. 2). Air temperature during winter and spring months (December to May) was higher in $2014(p<0.004$, $\mathrm{n}=360$ ), but daily mean precipitation during the same period was the same in both years $(p=0.976$, $\mathrm{n}=360$; Fig. 2). In 2013, the ice cover period was longer and additionally both the ice thickness as well as the snowpack thickness was greater in 2013 (Table 1). In 2013, the snow cover above ice cover reached the maximum, $18 \mathrm{~cm}$, in mid-March, while in 2014 the maximum was already in early-February, $28 \mathrm{~cm}$, and there was less than $1 \mathrm{~cm}$ of snow on the ice after 20 February. Also, in the forest, the snow cover lasted longer and was thicker in 2013 than in 2014 (Table 1).

Streams

\section{Discharge}

Differences in snow accumulation and melt were also reflected in the discharge pattern of the streams (Fig. 3). In 2013, the discharge decreased gradually during the period of ice-cover and increased rapidly after the mean air temperature reached $0{ }^{\circ} \mathrm{C}$ in April (Fig. 2). The start of the freshet was sudden due to the rapid increase in air temperature followed by the quick thawing of the accumulated snowpack (Table 1). The event reached its peak discharge $\left(1.57 \mathrm{~m}^{3} \mathrm{~s}^{-1}\right.$ and 1.82 $\mathrm{m}^{3} \mathrm{~s}^{-1}$ in the inlets and the outlet, respectively) five days after the onset of the freshet and the discharge then decreased gradually towards the end of May. In the following winter, the peak of melting event and the period of highest discharge (peak $0.46 \mathrm{~m}^{3} \mathrm{~s}^{-1}$ and 1.01 $\mathrm{m}^{3} \mathrm{~s}^{-1}$ in the inlets and the outlet, respectively) started already in mid-December and lasted until late January. Even though the snow cover was thickest in February, and it persisted until the end of March (Table 1), there was no clear spring freshet. Due to periods of high precipitation, the discharge increased slightly in three events in March-April, but the events were small in comparison to the thaw in January (Figs. 2, 3). In 2013, the snowmelt event completely masked the influence of precipitation. The water output from the lake was higher than the input through the streams, and the difference between the inputs and output was most prominent during the high flow events during the ice cover periods (Fig. 3). In 2013, the main inlet discharge was $51 \%$ and in $201458 \%$ of that in the outlet.

In all inflowing streams, the total discharge was higher in 2013 than in 2014 ( $p<0.000$; Fig. 4a, b). The mean discharge in the outlet was three times higher in 2013 than in 2014 , i.e., $0.32 \mathrm{~m}^{3} \mathrm{~s}^{-1}$ and 0.10 $\mathrm{m}^{3} \mathrm{~s}^{-1}$, respectively. In 2013, water was flowing in 15 inlet streams whereas in 2014 five out of the 15 inlets (S1, S4, S13, S14, S15) were dry. The secondary inlets were of greater importance in 2013; they covered 21 and $11 \%$ of the discharge in the outlet in 2013 and 2014, respectively. Taking together, the inlets covered $72 \%$ and $69 \%$ in 2013 and 2014 of that in the outlet. The lake thus receives water inputs also as overland 
Fig. 2 Daily mean air temperatures $\left({ }^{\circ} \mathrm{C}\right)$ and daily precipitation $(\mathrm{mm})$ from December to May in a 2013 and b 2014. Precipitation is shown in grey bars whereas air temperature is shown with solid line. The vertical dashed lines separate the periods of ice cover, freshet and open water

Table 1 Characteristics of the ice cover period
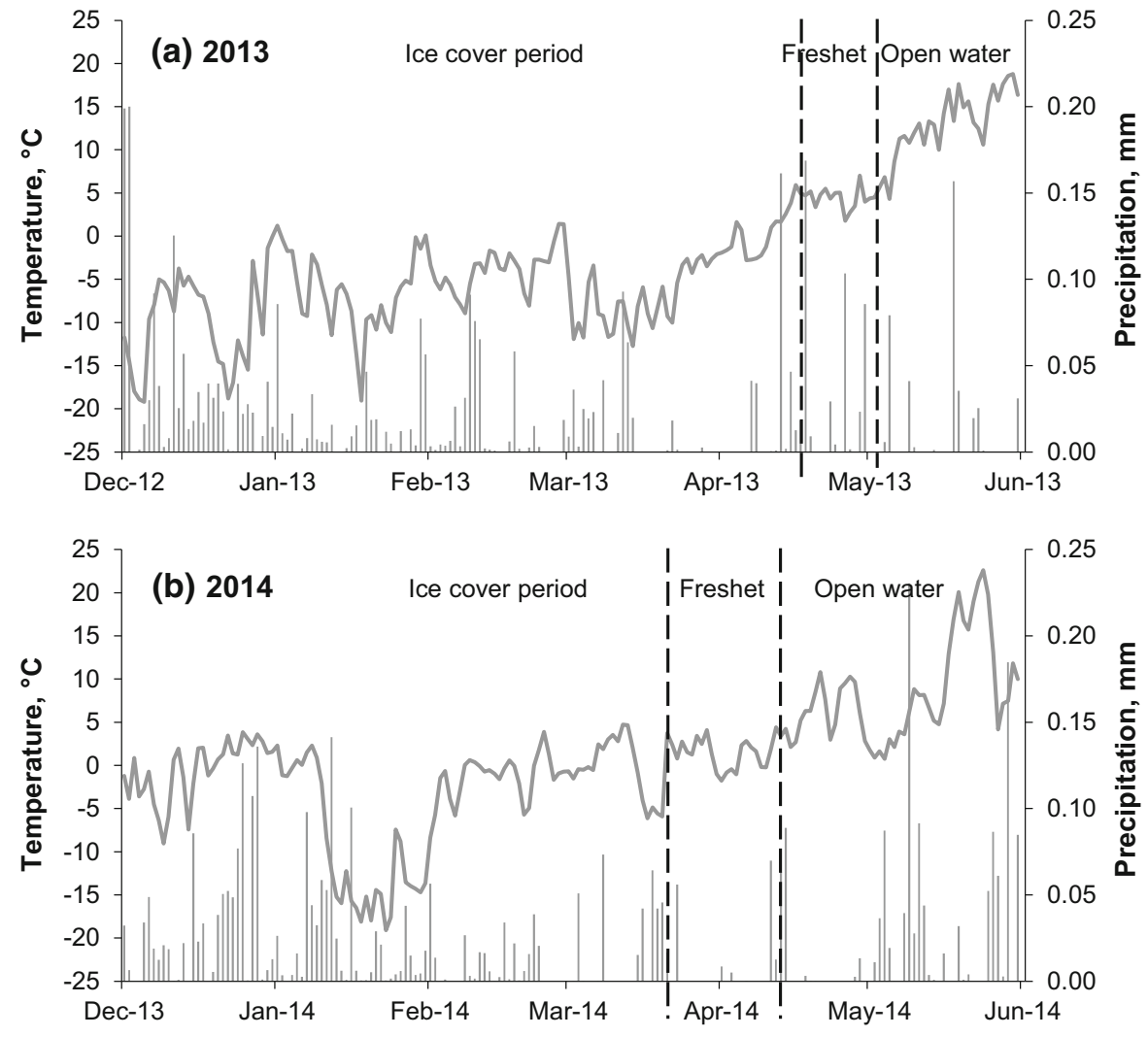

\begin{tabular}{|c|c|c|}
\hline & 2013 & 2014 \\
\hline \multicolumn{3}{|l|}{ Ice cover } \\
\hline Length, days & 155 & 137 \\
\hline Freeze over & 27 Nov (in 2012) & 27 Nov (in 2013) \\
\hline Ice out & 01 May & $12 \mathrm{Apr}$ \\
\hline \multicolumn{3}{|l|}{ Ice cover depth } \\
\hline Mean, cm & 32 & 24 \\
\hline Max, cm (date) & 44 (19 Mar) & 29 (29 Feb) \\
\hline \multicolumn{3}{|c|}{ Snow cover (above ice) } \\
\hline Mean, cm & 11 & 5 \\
\hline Max, cm (date) & 18 (19 Mar) & 28 (6 Feb) \\
\hline \multicolumn{3}{|c|}{ Snow cover (forest) } \\
\hline Lenght, days & 140 & 70 \\
\hline Mean, cm & 40 & 8 \\
\hline Max, cm (date) & 58 (18 Mar) & $15(3 \mathrm{Feb})$ \\
\hline Snow free, date & $29 \mathrm{Apr}$ & 31 Mar \\
\hline \multicolumn{3}{|c|}{ Precipitation (Dec-Apr) } \\
\hline Sum, mm & 192 & 156 \\
\hline
\end{tabular}


Fig. 3 The stream water discharge into the lake (all inlets together) and from the lake $\left(\mathrm{m}^{3} \mathrm{~s}^{-1}\right)$ in 2013 (a) and 2014 (b). The difference between the input and output is shown as a dark area
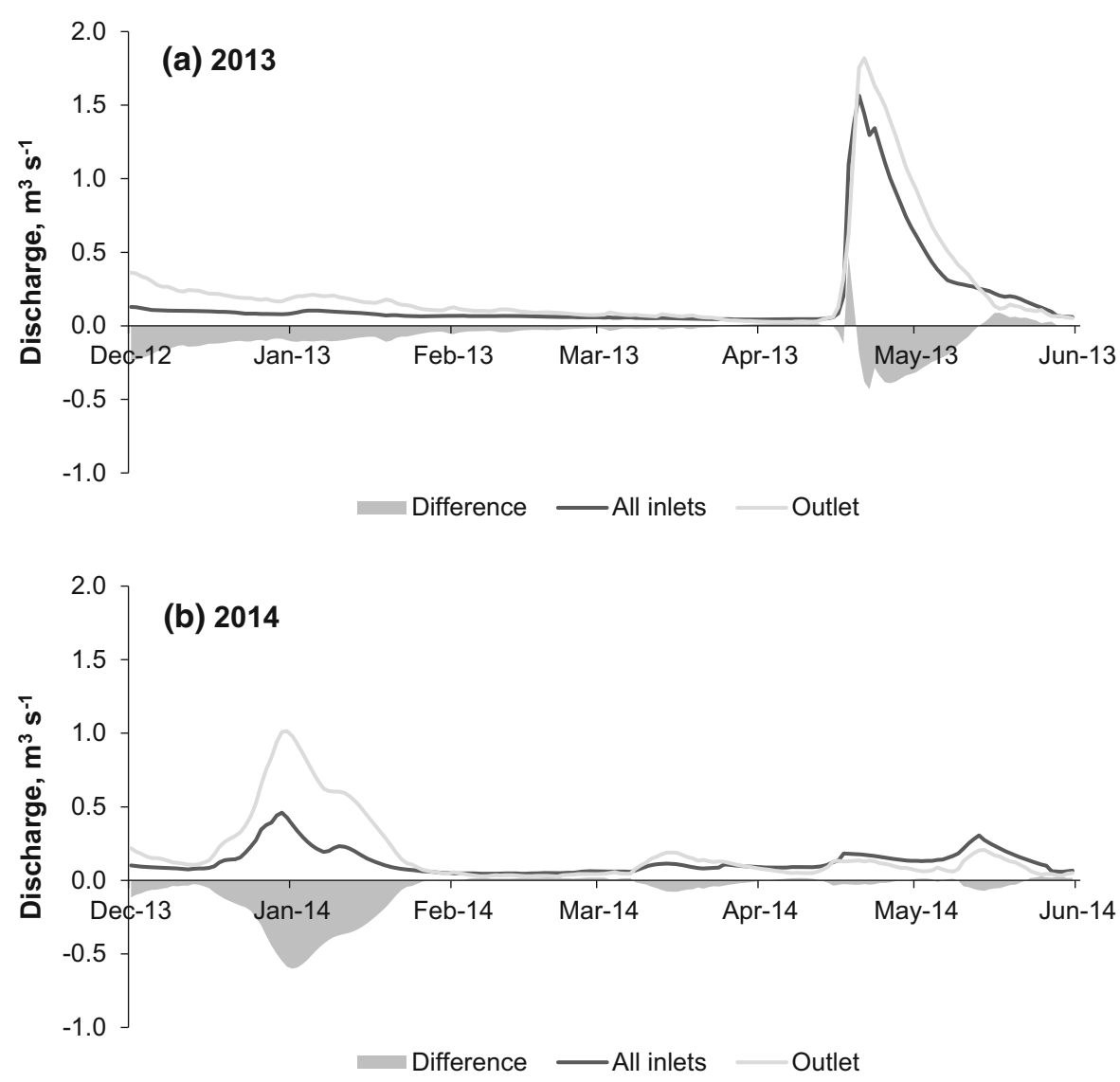

flow from the riparian zone, or through direct groundwater inputs, which were not directly measured.

\section{$\mathrm{CO}_{2}$ and DOC concentrations}

In general, the $\mathrm{CO}_{2}$ concentrations showed differences within and between the streams, but despite these substantial hydrological differences, there were only small concentration differences between the years (Fig. 4c, d). In the medium-sized streams the concentrations of $\mathrm{CO}_{2}$ were the same in both years $(p=0.29$, $\mathrm{n}=43$ ), whereas in the large-sized inlet streams, the concentrations were higher in 2013 than in 2014 $(p<0.028, \mathrm{n}=75)$, indicating stronger connection with shallow groundwater in 2013. However, in the large outlet stream, the concentrations were the same in both years $(p=0.303, \mathrm{n}=34)$. The small streams were completely dry in 2014 . However, when present, the small streams had the same $\mathrm{CO}_{2}$ concentration as the other streams $(p=0.448, \mathrm{n}=125)$.
The DOC concentrations had high instream variability and did not show apparent differences between the years in the medium $(p=0.773, \mathrm{n}=43)$ or largesized streams $(p=0.428, \mathrm{n}=77$; Fig. $4 \mathrm{e}, \mathrm{f})$. We measured very high DOC concentrations in 2013 in the stream number 4, whereas in 2014 that stream remained dry. DOC concentrations were lowest in small-sized streams, and of similar size in medium and large-sized streams $(p=0.032, \mathrm{n}=136)$. In the outlet stream, DOC concentrations were higher in 2013 than in $2014(p<0.000, \mathrm{n}=34)$.

Between the study years, the relationship between the concentrations of $\mathrm{CO}_{2}$ and DOC and discharge was stronger in 2013 than in 2014 (Table 2). In 2013, significant correlation between the variables were found in various stream size groups. In 2014, the relation between concentration and discharge was indistinguishable, and significant correlation with discharge was only found with DOC concentrations in medium sized streams and with $\mathrm{CO}_{2}$ concentrations in large sized streams. In all stream size groups, the 

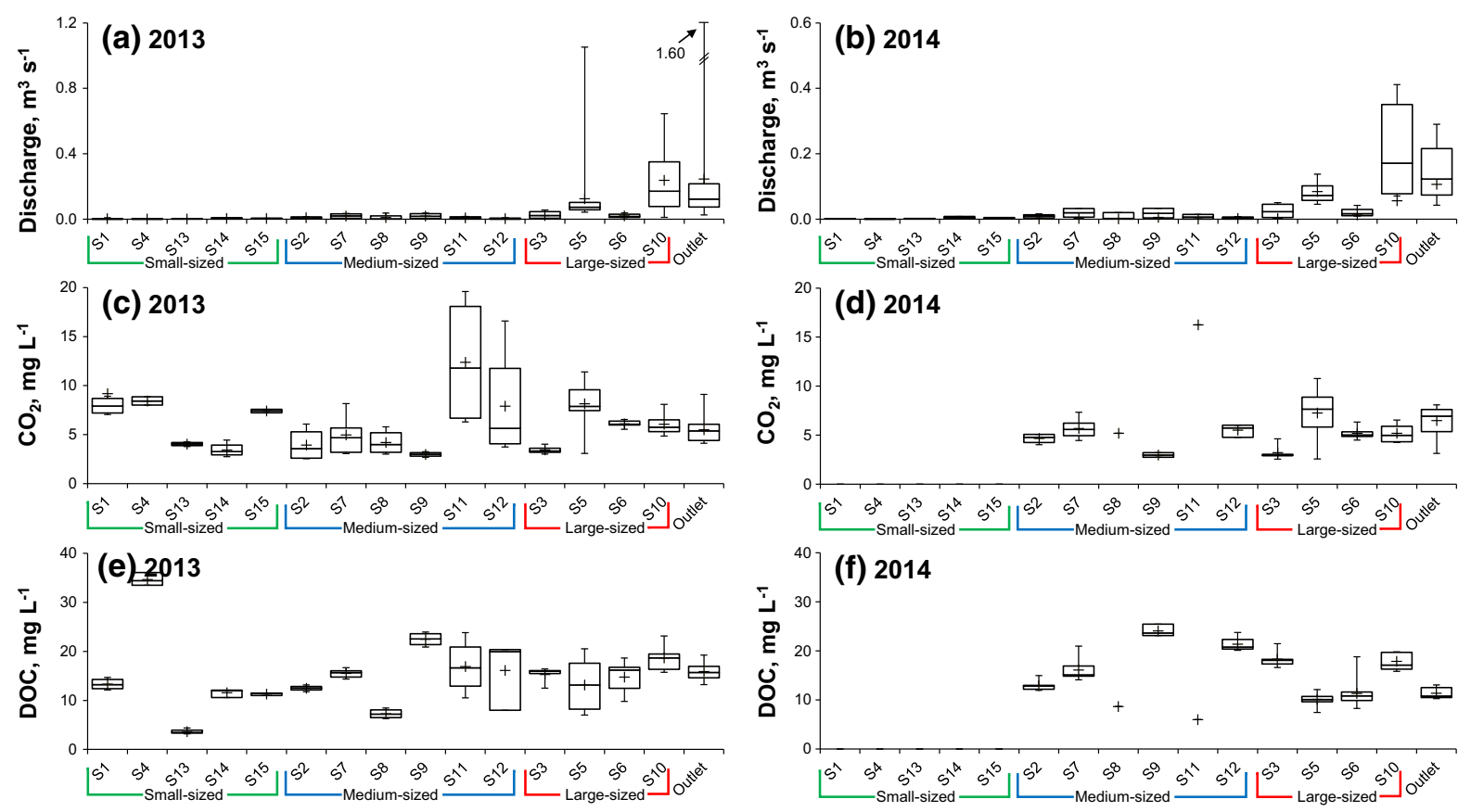

Fig. 4 Discharge $\left(\mathrm{m}^{3} \mathrm{~s}^{-1}\right)(\mathbf{a}, \mathbf{b})$, concentrations of $\mathrm{CO}_{2}$ $\left(\mathrm{mg} \mathrm{L}^{-1}\right)(\mathbf{c}, \mathbf{d})$ and DOC $\left(\mathrm{mg} \mathrm{L}^{-1}\right)(\mathbf{e}, \mathbf{f})$ in streams $(\mathrm{S} 1-\mathrm{S} 15$, outlet) organized by the size groups (small, medium and largesized) in both years. The boundaries of the box represent the

25th and 75th percentiles, a line within the box the median, + sign the mean and the whiskers indicate the maximum and minimum values. Note the different $y$-axis in discharge $(\mathbf{a}, \mathbf{b})$

Table 2 Spearman's correlation coefficients (2-tailed; r), and $p$-values (P) with significance level $<0.05(* *)$ and $<0.01(*)$ for $\mathrm{CO}_{2}$ and DOC concentrations in correlation with discharge $(\mathrm{Q})$ in streams divided into size groups

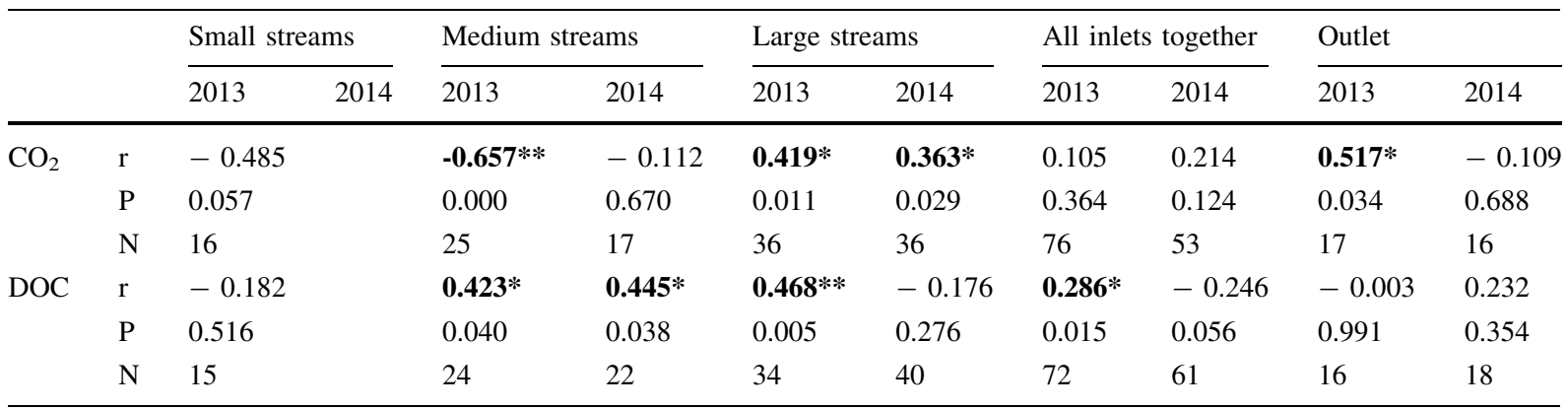

$N$ the number of samples

Statistically significant correlations are marked in bold

significant relationship between DOC concentrations and discharge was always positive, whereas the response of $\mathrm{CO}_{2}$ concentrations to discharge differed between the stream size groups. In medium sized streams, the increasing discharge in 2013 resulted as decreased $\mathrm{CO}_{2}$ concentrations, while in large sized streams and in the outlet this relationship was positive and the $\mathrm{CO}_{2}$ concentrations increased with increasing discharge. No clear relationship between DOC concentrations and discharge was found in small sized streams.

\section{Lateral transport of $\mathrm{CO}_{2}$ and DOC in streams}

The total amount of $\mathrm{CO}_{2}-\mathrm{C}$ and DOC-C transported into the lake was almost 1.5-fold higher in 2013 than in 
2014 (Fig. 5). However, the difference in daily lateral transport between the years was statistically significant neither with $\mathrm{CO}_{2}-\mathrm{C}(p=0.173, \mathrm{n}=364)$ nor DOC $-\mathrm{C}(p=0.174, \mathrm{n}=364)$. The DOC-C transport dominated the $\mathrm{C}$ transport in streams in both years. In 2013 and 2014, during the six months study period, the $\mathrm{CO}_{2}-\mathrm{C}$ input was 5760 and $3818 \mathrm{~kg}$, respectively, and the DOC-C input was 43,794 and $29,308 \mathrm{~kg}$, respectively. Thus, the transported $\mathrm{CO}_{2}-\mathrm{C}$ and $\mathrm{DOC}-\mathrm{C}$ in 2014 were $66 \%$ and $67 \%$ of the amounts transported in 2013, respectively following the much higher discharge in all streams in 2013 than in 2014. The output from the lake exceeded the total input of $\mathrm{CO}_{2}-\mathrm{C}$ as well as DOC-C in both years and similarly to input, the total output from the lake was higher in 2013 than in 2014, i.e., 7217 and $4744 \mathrm{~kg} \mathrm{CO}_{2}-\mathrm{C}$, in 2013 and 2014, respectively, and 65,659 and 37,442 kg DOCC, in 2013 and 2014, respectively. Thus, the output of $\mathrm{CO}_{2}-\mathrm{C}$ was $25 \%$ and $24 \%$ higher than the input in 2013 and 2014, respectively. Corresponding values for the DOC-C was 50\% and 28\% in 2013 and 2014, respectively. The differences in daily output between the years were statistically significant with both $\mathrm{CO}_{2}-$ $\mathrm{C}(p=0.028, \mathrm{n}=364)$ and DOC-C $(p=0.000$, $\mathrm{n}=364)$. In both years, the small and medium-sized streams only contributed 2 and $3 \%$ of the total transport of $\mathrm{CO}_{2}$ and DOC-C, respectively.

The timing of the lateral transport differed between the years and was connected to events with higher discharge. In 2014, the lateral transport mainly took place during the ice cover period, while in 2013 the transport was more evenly distributed, even though the highest inputs into the lake took place during the freshet (Fig. 5). In 2013, most of the transport in the inlets occurred during the freshet, when $51 \%$ of $\mathrm{CO}_{2}-$ $\mathrm{C}$ and $54 \%$ of DOC-C was transported. The corresponding values for the ice cover period were $33 \%$ of $\mathrm{CO}_{2}-\mathrm{C}$ and $24 \%$ of DOC-C. In 2014, the input was highest during the ice cover period, due to two different hydrological events: the small snowmelt, which induced small flooding in January, and the precipitation lasting few consecutive days at March. During these periods, $68 \%$ and $64 \%$ of $\mathrm{CO}_{2}-\mathrm{C}$ and DOC-C, respectively, was transported. During the freshet in 2014, the input was small and covered only $11 \%$ of $\mathrm{CO}_{2}-\mathrm{C}$ and $6 \%$ of DOC $-\mathrm{C}$ transport. The relation between $\mathrm{CO}_{2}-\mathrm{C}$ and DOC-C indicate higher input of DOC-C during melting events and lower during cold periods, although the relation during the whole study remained constant; $12 \%$ of the laterally
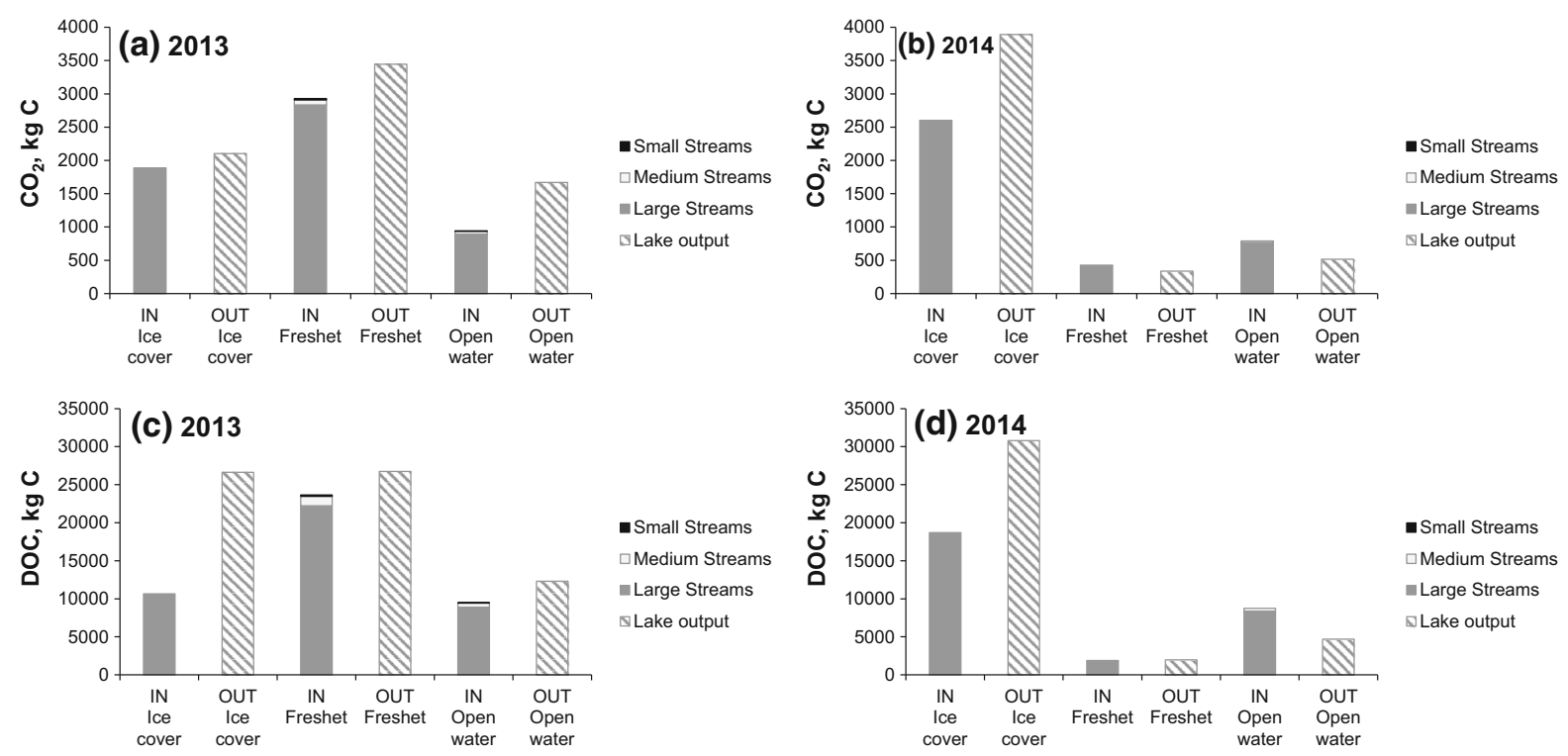

Fig. $5 \mathrm{CO}_{2}-\mathrm{C}(\mathrm{kg} ; \mathbf{a}, \mathbf{b})$ and DOC-C (kg; c, d) input into the lake in different sized streams (small, medium and large-sized streams) and from the lake (lake output) during the ice cover, freshet and open water periods in 2013 and 2014 
transported input $\mathrm{C}$ was $\mathrm{CO}_{2}-\mathrm{C}$ and $88 \%$ of $\mathrm{DOC}-\mathrm{C}$ during both years.

The timing of the output of $\mathrm{CO}_{2}-\mathrm{C}$ seemed to have a similar pattern with the highest transport in a freshet in 2013 (48\%) and ice cover period in 2014 (82\%). The outputs of DOC-C, however, were equal in size during the ice cover period and freshet in $2013,41 \%$ in both periods indicating that the discharge was not the only factor defining the output. In $2014,82 \%$ of the DOC-C output took place in the ice cover period. Similar to the input, the total output was dominated by the $\mathrm{DOC}-\mathrm{C}$ and with no differences between the years: $10 \%$ of the $\mathrm{C}$ was in $\mathrm{CO}_{2}-\mathrm{C}$ and $90 \%$ in DOCC.
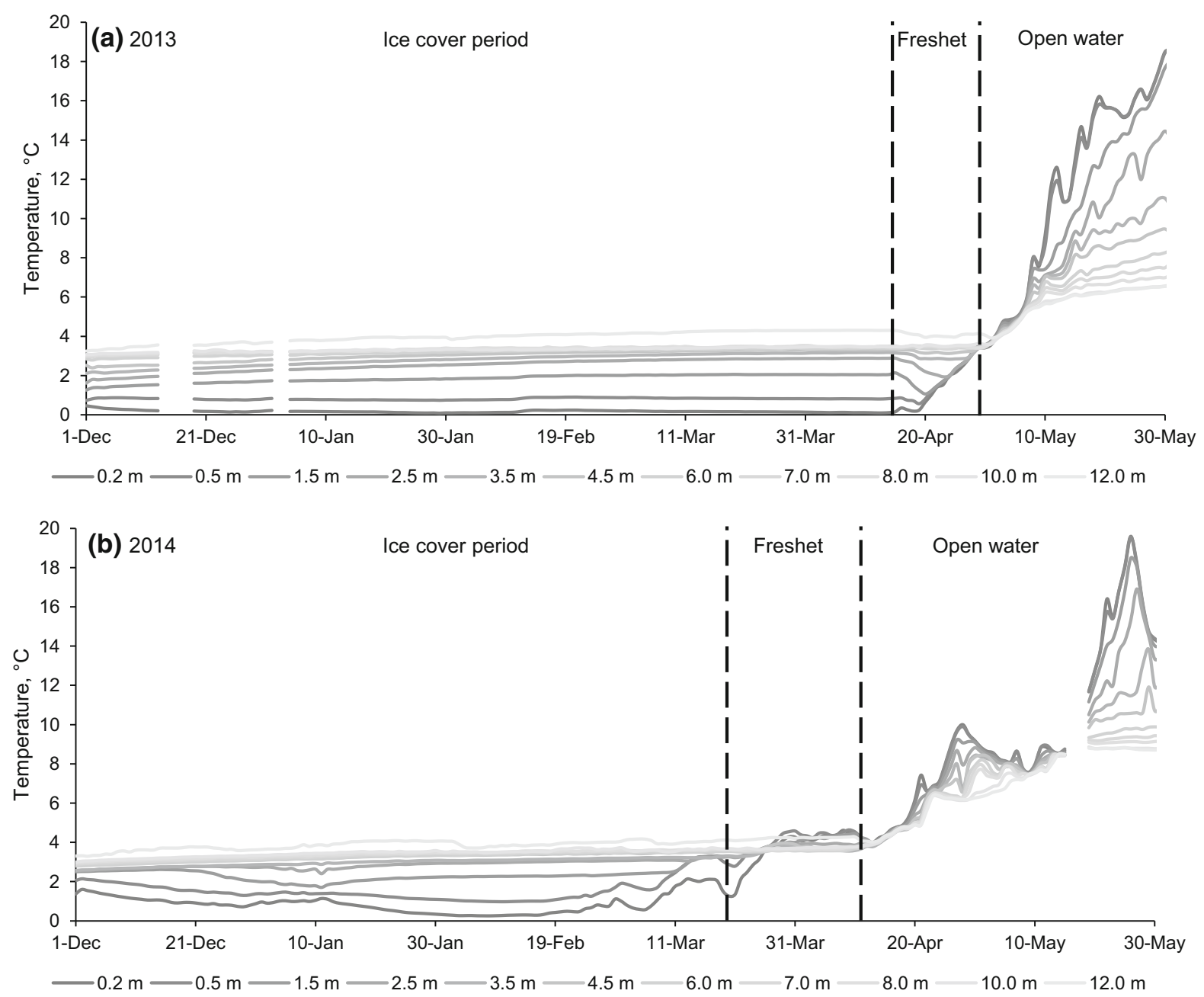

Fig. 6 Water temperature $\left({ }^{\circ} \mathrm{C}\right)$ in different depths of the lake from December to May in 2013 (a) and 2014 (b). The vertical dashed lines
separate the periods of ice cover, freshet and open water

Fig. 6 Water temperature $\left({ }^{\circ} \mathrm{C}\right)$ in different depths of the lake from December to May in $2013(\mathbf{a})$ and $2014(\mathbf{b})$. The vertical dashed lines
separate the periods of ice cover, freshet and open water
Lake

\section{Temperature}

In 2013, when the lake was ice-covered for 155 days, the lake showed inverse stratification with temperatures close to $0{ }^{\circ} \mathrm{C}$ below the ice (Fig. 6a). At the onset of the freshet, temperatures from the depths of $0.5 \mathrm{~m}$ to $4.5 \mathrm{~m}$ decreased further. From 19 April onwards, the surface temperature increased gradually and showed a diurnal variation. The lake was stratified at the onset of the freshet, with the thermocline at a depth of $4.0 \mathrm{~m}$. However, the mixing started in the middle of the freshet, but the turnover was not complete until 2 May, i.e., one day after the ice-out on 1 May. 


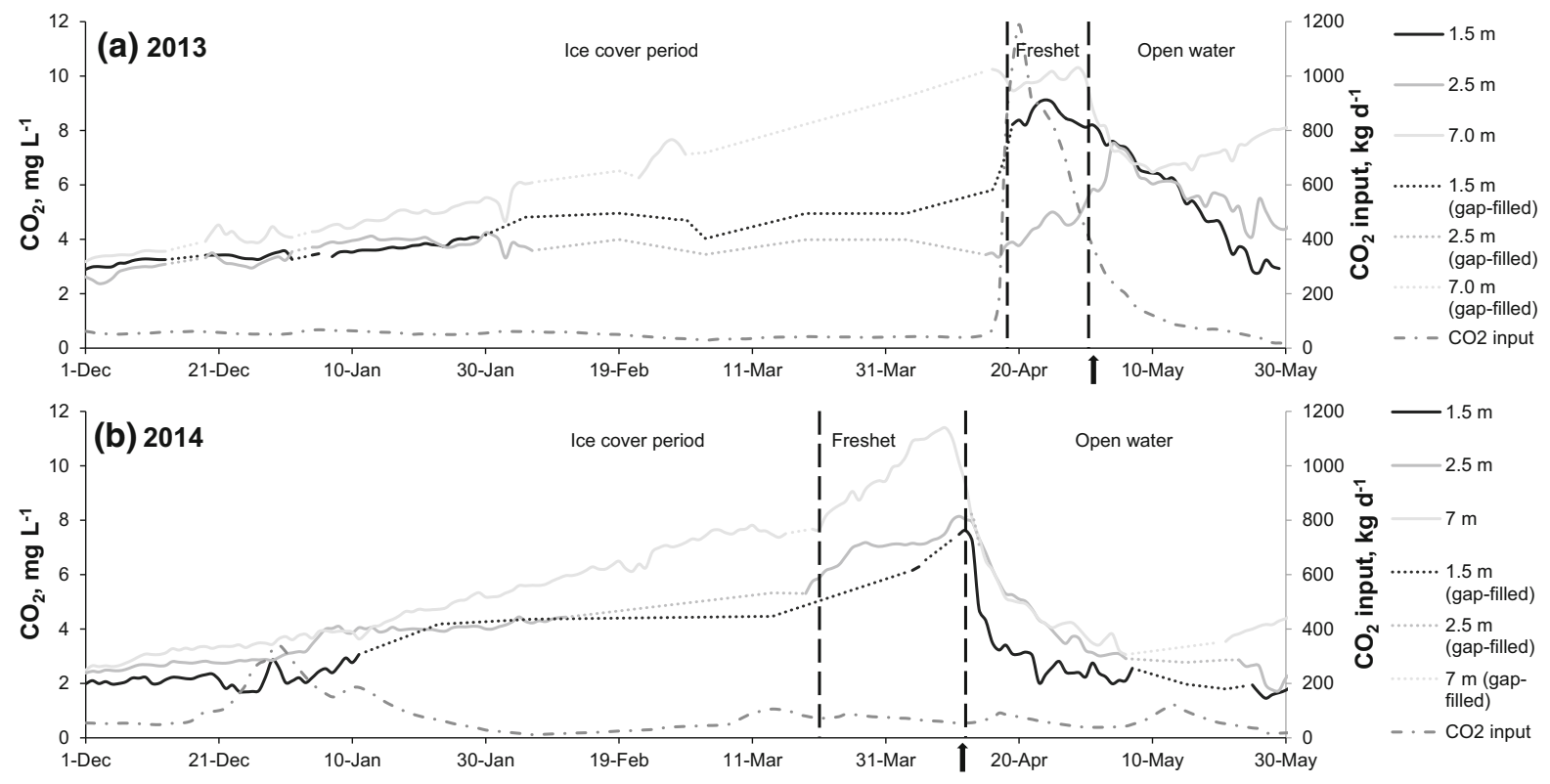

Fig. $7 \mathrm{CO}_{2}$ concentrations $\left(\mathrm{mg} \mathrm{L}^{-1}\right)$ at $1.5,2.5$, and $7.0 \mathrm{~m}$ depths and the $\mathrm{CO}_{2}$ input $\left(\mathrm{kg} \mathrm{day}^{-1}\right)$ into the lake in streams in 2013 (a) and 2014 (b). For each depth, dotted lines represent the

The warm period in January 2014 did not affect the under-ice thermal stratification, although the surface water $(<2.5 \mathrm{~m})$ temperatures fluctuated slightly after the hydrological peak entered the lake (Fig. 6b). In general, the warmer year resulted in higher lake water temperatures. In March, the snowless ice-cover was already thin (Table 1), and as a result, the below-ice temperatures were higher than in 2013. During the last ten days before ice-out, the surface water under the ice was $2.0^{\circ} \mathrm{C}$ warmer than in 2013. Similar to 2013, there was a diurnal variation in water temperature under the ice. The surface water then warmed up gradually, and the water column was homothermal at $3{ }^{\circ} \mathrm{C}$ from mid-March until the ice-out on 12 April. After that, the water column warmed and finally stratified at the end of May.

\section{$\mathrm{CO}_{2}$ and DOC concentrations in the lake}

During the ice cover period in $2013, \mathrm{CO}_{2}$ concentrations at $7.0 \mathrm{~m}$ depth increased, while concentrations at 1.5 and $2.5 \mathrm{~m}$ remained constant (Fig. 7a). On the first week of the ice cover period, the mean concentrations of $\mathrm{CO}_{2}$ at all depths were similar, i.e., 3.0, 2.6 and $3.4 \mathrm{mg} \mathrm{L}^{-1}$ at the depths of $1.5,2.5$ and $7.0 \mathrm{~m}$, respectively. Concentrations at $7.0 \mathrm{~m}$ then increased gap-filled periods. The vertical dashed lines separate the periods of ice cover, freshet and open water. The spring turn-over is marked with the black arrow

clearly, so that just before the start of the freshet, the concentrations in the two upper depths were only half of that at $7.0 \mathrm{~m}$ depth. When the freshet started, the concentrations at $1.5 \mathrm{~m}$ depth increased within four days close to concentrations at $7.0 \mathrm{~m}$. At the same period, the lake stayed stratified. The concentrations at $2.5 \mathrm{~m}$ depth increased smoothly after ten days from the onset of the freshet, simultaneously with the lake surface water mixing. During the freshet, the concentrations at $7.0 \mathrm{~m}$ did not increase anymore. The mean concentrations during the freshet were 8.3, 4.3, and $10.0 \mathrm{mg} \mathrm{L}^{-1}$ at the depths of $1.5,2.5$, and $7.0 \mathrm{~m}$, respectively. At the ice-out, the $\mathrm{CO}_{2}$ concentration was lowest at $2.5 \mathrm{~m}, 5.8 \mathrm{mg} \mathrm{L}^{-1}$, and highest at $7.0 \mathrm{~m}, 8.4 \mathrm{mg} \mathrm{L}^{-1}$. Since $\mathrm{CO}_{2}$ accumulated in the water column was rapidly released to the atmosphere after the ice-out (results not shown), $\mathrm{CO}_{2}$ concentrations at all depths dropped clearly at the beginning of May. In mid-May, the concentrations at $7.0 \mathrm{~m}$ started to increase again, while concentrations closer to surface decreased. The mean concentrations during the open water period were $5.4,5.7$, and $7.3 \mathrm{mg} \mathrm{L}^{-1}$ at $1.5,2.5$, and $7.0 \mathrm{~m}$ depths, respectively.

In 2014, the $\mathrm{CO}_{2}$ dynamics was more unstable than in 2013, and thus in agreement with water column stratification (Fig. 7b; 6b). At the beginning of the ice 
cover period, the concentrations were low; 2.0, 2.5, and $2.6 \mathrm{mg} \mathrm{L}^{-1}$ at $1.5 \mathrm{~m}, 2.5 \mathrm{~m}$, and $7.0 \mathrm{~m}$, respectively. The warm period in December-January resulted in smooth increases in $\mathrm{CO}_{2}$ concentrations at $1.5 \mathrm{~m}$ depth, but it did not have clear influences on the concentrations at $2.5 \mathrm{~m}$ and $7.0 \mathrm{~m}$, which increased steadily until the freshet. The mean concentrations during the freshet were 5.9, 7.0, and $9.7 \mathrm{mg} \mathrm{L}^{-1}$ at depths of $1.5,2.5$, and $7.0 \mathrm{~m}$, respectively. The water mixing started one week after the onset of the freshet but did not affect deeper ( $>6 \mathrm{~m}$ ) layers before the four last days of the freshet, and the turnover completed on 11 April, one day before the ice-out on 12 April. The concentrations at all depths increased to their maxima just before the ice-out simultaneously with complete turnover. After the ice-out, concentrations rapidly declined until May. The mean concentrations during the open water period were relatively low, 2.6, 3.6, and $4.3 \mathrm{mg} \mathrm{L}^{-1}$ at $1.5,2.5$, and $7.0 \mathrm{~m}$, respectively.

The mean concentrations during the ice cover period were significantly lower in 2014 than in 2013 at $1.5 \mathrm{~m}(p=0.00, \mathrm{n}=14)$ and $7.0 \mathrm{~m} \quad(p=0.00$, $\mathrm{n}=14$ ), but the concentrations at $2.5 \mathrm{~m}$ did not differ ( $p=0.08, \mathrm{n}=14)$. Concentrations during the freshet in 2014 were lower at $1.5 \mathrm{~m}(p=0.00, \mathrm{n}=36)$ and at $2.5 \mathrm{~m}$ higher $(p=0.00, \mathrm{n}=36)$ than in 2013 and at $7.0 \mathrm{~m}$ depth the concentrations were the same in both years $(p=0.48, \mathrm{n}=36$ ). In 2014 , the concentrations during the open water period were lower than in 2013 at all depths $(1.5 \mathrm{~m}, p=0.00, \mathrm{n}=82 ; 2.5 \mathrm{~m}$, $p=0.00, \mathrm{n}=82 ; 7.0 \mathrm{~m}, p=0.00, \mathrm{n}=82$ ).

The mean DOC concentrations in the lake surface during the ice cover period were 16.2 and $13.2 \mathrm{mg} \mathrm{L}^{-1}$ in 2013 and 2014, respectively (Table 3). After the ice-out, the concentrations dropped to 14.0 and $10.7 \mathrm{mg} \mathrm{L}^{-1}$ in 2013 and 2014, respectively. The concentrations close to the bottom $(12.0 \mathrm{~m})$ were lower in comparison to the surface concentrations, but the decline from the values of the ice cover period to open water period was small.

\section{Discussion}

$\mathrm{CO}_{2}$ and DOC concentrations in streams

Despite the substantial hydrological differences between the study years, the mean concentrations of $\mathrm{CO}_{2}$ and DOC in the streams showed only small differences. This result is against the hypothesis and is surprising since the terrestrial $\mathrm{C}$ flow paths into the adjacent aquatic surfaces are known to be closely connected to hydrology (Dinsmore et al. 2013b) and environmental conditions, such as differences in air temperature and winter precipitation (Tiwari et al. 2018). In terms of the amount of precipitation, the winters were similar, but the accumulation of snow and thus the intensity of spring freshet differed. This resulted in higher discharge peak values in 2013 and as a result, also the concentrations of $\mathrm{CO}_{2}$ and DOC varied more than in warm year, indicating that after the warm winter, the spring conditions resembled more baseflow conditions than flashy extreme event conditions. Also, the relationship between the concentrations of $\mathrm{CO}_{2}$ and DOC and stream discharge was stronger in 2013 than in 2014. Our data is supportive of the idea that the hydrological carbon source areas and the connecting flow paths differ during different hydrological conditions both laterally across the landscape and vertically due to the shallow groundwater table changes.

The $\mathrm{CO}_{2}$ dynamics in the small and medium-sized streams around Lake Kuivajärvi suggest that they are not predominantly connected to $\mathrm{C}$ enriched groundwater sources, but rather that melting water dilutes the concentrations in the stream channel. This is in

Table 3 Mean DOC concentrations $\left(\mathrm{mg} \mathrm{L}^{-1}\right)$ and standard deviation in brackets in lake surface $(0.2 \mathrm{~m})$ and bottom (12.0 $\left.\mathrm{m}\right)$ during the ice cover and open water periods in each year. $n=$ number of samples (subscripts ic: ice cover, ow: open water)

\begin{tabular}{llllll}
\hline Sampling depth $(\mathrm{m})$ & $\mathrm{N}_{\mathrm{ic}}$ & $\mathrm{N}_{\mathrm{ow}}$ & Year & DOC Ice cover $\left(\mathrm{mg} \mathrm{L}^{-1}\right)$ & ${\text { DOC Open water }\left(\mathrm{mg} \mathrm{L}^{-1}\right)}^{2}$ \\
\hline 0.2 & 4 & 2 & 2013 & $16.2(2.8)$ & $14.0(1.7)$ \\
12.0 & 9 & 4 & 2014 & $13.2(1.4)$ & $10.7(0.2)$ \\
& 4 & 2 & 2013 & $14.2(1.1)$ & $13.9(0.3)$ \\
& 8 & 4 & 2014 & $11.3(0.6)$ & $10.7(0.5)$ \\
\hline
\end{tabular}


contrast to the larger streams, where the increased discharge led to increases in $\mathrm{CO}_{2}$ concentrations. While in the smallest streams there was no relationship between $\mathrm{CO}_{2}$ discharge, in the medium-sized streams the correlation with $\mathrm{CO}_{2}$ and discharge was negative, i.e., in these streams, the dilution effect through the thawing snow and possible rain events were contributing to stream $\mathrm{CO}_{2}$ concentrations. Dilution by increased water inputs in spring has also been observed before (Dinsmore et al. 2011; Dyson et al. 2011) and has been explained by $\mathrm{CO}_{2}$ poor water flowing over the frozen soil surface (Laudon et al. 2004). In contrast to diluted $\mathrm{CO}_{2}$ concentrations in the medium-sized streams, DOC concentrations showed a positive relationship with discharge in both years. This is a typical result found in earlier studies from similar Boreal ecosystems (Laudon et al. 2011; Pumpanen et al. 2014). The correlation between DOC concentrations and discharge could result from the different location of DOC in comparison with $\mathrm{CO}_{2}$ located in deeper layers (Rasilo et al. 2011) in the soil profile, which would explain the high DOC concentrations in the shallow streams without a connection with groundwater sources. When water rich with DOC percolates or infiltrates through the mineral soil, most of the DOC precipitates in the illuvial layer of the podzolic soil (Pumpanen et al. 2014). Thus, the deeper groundwater usually contains less DOC compared to the superficial flow. The largest streams were better connected to groundwater sources, and their $\mathrm{CO}_{2}$ concentrations increased concomitantly with the increasing discharge, a pattern described earlier in Boreal streams after significant precipitation events (Rasilo et al. 2011). Rapid snowmelt events flushed and filled the soil pores releasing soil-derived $\mathrm{CO}_{2}$ into the streams. Leith et al. (2015) observed the highest riparian $\mathrm{CO}_{2}$ export in $30-50 \mathrm{~cm}$ depth and continuous but smaller export in layers deeper than $65 \mathrm{~cm}$. In our study location, the large streams were also the deepest (data not shown), reinforcing the idea that deeper soil layers were the source of $\mathrm{CO}_{2}$ in the large streams around Lake Kuivajärvi. The deeper soil layers as a source of $\mathrm{CO}_{2}$ is consistent with the lower $\mathrm{CO}_{2}$ concentrations in these streams in 2014 when the spring freshet was very small.

Current hydrological conditions are crucial for the soil water mobilization and further, to $\mathrm{C}$ mobilization, because the infiltration rate differs in the dry and wet soils. While the response in wet soils is immediate, in dry soils, the time lag between the event and water flow could be up to 36 days (Ilvesniemi et al. 2010). However, the soils in the upland catchment area next to the lake typically reach the maximum water holding capacity in late autumn or early winter (Ilvesniemi et al. 2010), which would predict the fast response of events during the ice cover period and freshet. However, we know, that the summer and autumn 2012 were wet, and 2013 dry in comparison with a typical year (Miettinen et al. submitted), which probably resulted in lower response and longer water residence time in soils in 2014. The influence of the previous seasons and years on DOC (Ågren et al. 2010; Tiwari et al. 2018) and $\mathrm{CO}_{2}$ (Einola et al. 2011; Rantakari and Kortelainen 2005) concentrations in aquatic surfaces have already been addressed in earlier studies. This is also following the $\mathrm{C}$ dynamics in the large-sized streams, which indicated stronger groundwater influence during the typical spring 2013.

\section{Lateral transport}

Changes in the timing of precipitation and snowmelt were the controlling factors behind the total riverine transport, and as expected, the timing of $\mathrm{C}$ transport differed significantly between the years. In 2013, the lateral transport took place mainly during the freshet; i.e., approximately half of the total $\mathrm{C}$ transport occurred then. Hydrologically, the year 2013 represented the typical spring freshet, when most of the annual C load is transported (Dinsmore et al. 2011; Dyson et al. 2011; Laudon et al. 2004). The DOC export was comparable with the earlier springtime measurements on DOC (Pumpanen et al. 2014) whereas $\mathrm{CO}_{2}$ was slightly higher (Dyson et al. 2011). In 2014 instead, the lateral transport in streams during the freshet was ca. $90 \%$ lower in comparison to 2013, and the transport mainly occurred during the winter months. The $\mathrm{CO}_{2}$ and DOC transport in the streams was then $c a .2 / 3$ of the total transport of the study period, i.e., the ice-covered winter months were more important than the spring freshet. Winter is typically a period with low flow and small transport, but in 2014 the winter time transport was much higher than reported earlier (e.g. Ågren et al. 2007; Leith et al. 2015), indicating changes in the timing of $C$ transport under future warmer conditions. Climate models predict increases in winter precipitation and warmer winters (IPCC 2013), which will shift the lateral C 
transport towards winter months. However, our study shows that the change in timing does not necessarily change the daily $\mathrm{C}$ transport. The proportion of organic and inorganic $\mathrm{C}$ in lateral transport also remains unchanged.

Under ice dynamics in lake coupled with lateral transport

Despite the similarities in total lateral transport between the years, the concentrations of $\mathrm{CO}_{2}$ in the uppermost layer (1.5 $\mathrm{m}$ depth) in the lake were lower in 2014 than in 2013, which was against our hypothesis. However, there was apparent synchrony between the lateral $\mathrm{C}$ input and lake $\mathrm{CO}_{2}$ dynamics during the ice cover period and the freshet. Depending on the intensity of the hydrological events and water storage conditions in the catchment, the external inputs entered the lake either as surface or deeper groundwater inputs, influencing the concentrations at different depths. $\mathrm{CO}_{2}$ concentrations in the uppermost layer started to increase immediately after the onset of the thaw period, regardless of the season, i.e., during the ice cover period in the middle of winter (2014) or the freshet (2013). The increase was fast and drastic in 2013, while in 2014 the concentrations increased only gradually, which agrees with the size of the lateral C input into the lake. At the time of the supposed terrestrial signal, the lake was clearly thermally stratified in both years and this forced the cold, surface water input (stream water temperature between 0.5 and $1.0^{\circ} \mathrm{C}$ ) to flow to the surface layers with the same temperature (Bengtsson 1996), i.e., to the uppermost layer under the ice cover. In the end of the freshet in 2013, after the mixing of the water column had started, the clear terrestrial signal was lost, and the increases in concentrations could have also resulted from in-lake water movements (MacIntyre et al. 2018; Pasche et al. 2019).

While most of the water entered the lake as surface flow, the volume of the output water exceeded the volume of input waters during ice-cover and freshet periods indicating additional inputs, e.g., deeper groundwater flows (Supplementary Fig. S1). Deeper groundwater can provide a small but continuous source of $\mathrm{CO}_{2}$ in surface waters (Leith et al. 2015), and these inputs can be responsible for up to $64 \%$ of the total external inorganic $\mathrm{C}$ inputs into the lake (Einarsdottir et al. 2017). Groundwater flow paths in the soil differ from the event-related surface inputs and are affected, for example, by hydraulic conductivity and porosity of the system (Alley et al. 2002). Thus, depth-specific groundwater inputs to the lake are hard to predict. Thus, groundwater inputs, containing a high quantity of $\mathrm{CO}_{2}$ (e.g. Rasilo et al. 2011) are a plausible explanation for increases of $\mathrm{CO}_{2}$ deeper down in the water column during the high flow events (Fig. 3). However, we can likely expect, that in thermally stratified lake during ice-cover period, the surface and deeper groundwater $\mathrm{C}$ flows were distributed between hypolimnion and epilimnion according to the temperature gradient, and the deeper groundwater inputs were small in $\mathrm{C}$ dynamics in the uppermost layer $(1.5 \mathrm{~m})$. Usually, the constant $\mathrm{CO}_{2}$ increase under ice cover is due to a combination of organic matter inputs and microbially-driven decomposition under conditions with limited photosynthesis during the ice cover period (Demarty et al. 2011; Huotari et al. 2009; Striegl et al. 2001; Vachon et al. 2017). High DOC inputs particularly in 2014 can explain the observed increase of $\mathrm{CO}_{2}$ concentration in the lake during the low flow periods and are supported by DOC concentration decline (data not shown), which is an indication of efficient mineralization. Moreover, sediment respiration can also be a significant source of under-ice $\mathrm{CO}_{2}$ in oligotrophic lakes such as arctic lakes (MacIntyre et al. 2018) and shallow subarctic lakes (Karlsson et al. 2008). Since mineralization of DOC is temperature and substrate dependent (Gudasz et al. 2010), sediment respiration alone cannot explain the sudden increases of subsurface $\mathrm{CO}_{2}$ concentrations during the stratification period, but it can be important for $\mathrm{CO}_{2}$ at the ice-out.

\section{Conclusions}

Our findings have significant implications for the understanding of $\mathrm{C}$ dynamics in an interface of Boreal lentic and lotic ecosystems, especially under future climatic conditions where snow may not persist throughout the winter, emerging from this intensive two-year study with distinctively different winter and spring freshet. In the studied landscape surrounded by managed forests but with an unregulated lake, the hydrological regime strongly altered the $\mathrm{C}$ dynamics in the land-stream-lake continuum. When the winter was warm (2014) with a thin accumulated snow cover, 
the peak in $\mathrm{C}$ transport shifted from the spring freshet to mid-winter. However, the drastic change in timing does not necessarily change the amount of daily $\mathrm{C}$ transport. We also found that most of the $\mathrm{C}$ was consistently transported as DOC, and the relation of $\mathrm{CO}_{2}-\mathrm{C}$ and DOC $-\mathrm{C}$ was the same in both study years, i.e., $12 \%$ of the $\mathrm{C}$ transported into the lake was in the form of $\mathrm{CO}_{2}$ and $88 \%$ in DOC. The stream $\mathrm{CO}_{2}$ and DOC concentrations showed different responses to hydrology, depending on the size of the streams and thus the connection to shallow groundwater inputs. Regardless of the hydrological regime, the bulk of the carbon was always transported in the largest streams. Besides the $\mathrm{C}$ input via streams, the high water and $\mathrm{C}$ export from the lake in comparison with inlet indicate alternative $\mathrm{C}$ inputs into the lake, possibly via deeper groundwater or higher $\mathrm{C}$ production and mineralization in the shallow end of the lake close to the outlet.

Our results emphasize the role of lakes in the landscape and show, that the external $\mathrm{C}$ input, whether taking place just before the ice-out or during the ice cover period, increases the $\mathrm{CO}_{2}$ concentrations in the upper layers of the lake and can thus increase the atmospheric release at the ice-out. Thus, to understand the future springtime $\mathrm{C}$ dynamics under the changing climate, all components of the terrestrial-aquatic continuum should be studied concomitantly.

Acknowledgements Open access funding provided by University of Helsinki including Helsinki University Central Hospital. This study was funded by the Academy of Finland ICOS project (263149), EU ICOS project (211574), EU GHGEurope project (244122), EU-project GHG-LAKE, DEFROST (Nordforsk) project and the Academy of Finland (projects 218094 and 139291) and the Finland Centre of Excellence programme (project 1118615). HM wants to thank Finnish Society of Forest Science and Kempe Foundation for financial support. We thank the staff of Hyytiälä Forestry Field Station, Tamás Molnár and María Luisa Gutiérrez de los Rios for helping with the fieldwork and carrying out laboratory analyses. We thank Joss Ratcliffe for language revision.

Open Access This article is licensed under a Creative Commons Attribution 4.0 International License, which permits use, sharing, adaptation, distribution and reproduction in any medium or format, as long as you give appropriate credit to the original author(s) and the source, provide a link to the Creative Commons licence, and indicate if changes were made. The images or other third party material in this article are included in the article's Creative Commons licence, unless indicated otherwise in a credit line to the material. If material is not included in the article's Creative Commons licence and your intended use is not permitted by statutory regulation or exceeds the permitted use, you will need to obtain permission directly from the copyright holder. To view a copy of this licence, visit http://creativecommons.org/licenses/by/4.0/.

\section{References}

Ågren A, Buffam I, Jansson M, Laudon H (2007) Importance of seasonality and small streams for the landscape regulation of dissolved organic carbon export. J Geophys Res Biogeosci 112(G3):G03003

Ågren A, Haei M, Köhler SJ, Bishop K, Laudon H (2010) Regulation of stream water dissolved organic carbon (DOC) concentrations during snowmelt; the role of discharge, winter climate and memory effects. Biogeosciences 7(9):2901-2913

Algesten G, Sobek S, Bergström AK, Ågren A, Tranvik Lars J, Jansson M (2003) Role of lakes for organic carbon cycling in the boreal zone. Glob Chang Biol 10(1):141-147

Alley WM, Healy RW, LaBaugh JW, Reilly TE (2002) Flow and storage in groundwater systems. Science 296(5575): 1985

Aufdenkampe AK, Mayorga E, Raymond PA, Melack JM, Doney SC, Alin SR, Aalto RE, Yoo K (2011) Riverine coupling of biogeochemical cycles between land, oceans, and atmosphere. Front Ecol Environ 9(1):53-60

Baehr MM, DeGrandpre MD (2004) In situ $p \mathrm{CO}_{2}$ and $\mathrm{O}_{2}$ measurements in a lake during turnover and stratification: observations and modeling. Limnol Oceanogr 49(2):330-340

Battin TJ, Luyssaert S, Kaplan LA, Aufdenkampe AK, Richter A, Tranvik LJ (2009) The boundless carbon cycle. Nat Geosci 2(9):598-600

Bengtsson L (1996) Mixing in ice-covered lakes. Hydrobiologia 322(1):91-97

Bernhardt ES, Blaszczak JR, Ficken CD, Fork ML, Kaiser KE, Seybold EC (2017) Control points in ecosystems: Moving beyond the hot spot hot moment concept. Ecosystems 20(4):665-682

Bishop K, Pettersson C, Allard B, Lee Y-H (1994) Identification of the riparian sources of aquatic dissolved organic carbon. Environ Int 20(1):11-19

Campeau A, Wallin MB, Giesler R, Löfgren S, Mörth C-M, Schiff S, Venkiteswaran JJ, Bishop K (2017) Multiple sources and sinks of dissolved inorganic carbon across Swedish streams, refocusing the lens of stable C isotopes. Sci Rep 7(1):9158

Cole JJ, Prairie YT, Caraco NF, McDowell WH, Tranvik LJ, Striegl RG, Duarte CM, Kortelainen P, Downing JA, Middelburg JJ, Melack J (2007) Plumbing the global carbon cycle: Integrating inland waters into the terrestrial carbon budget. Ecosystems 10(1):172-185

Cortés A, MacIntyre S, Sadro S (2017) Flowpath and retention of snowmelt in an ice-covered arctic lake. Limnol Oceanogr 62(5):2023-2044

Demarty M, Bastien J, Tremblay A (2011) Annual follow-up of gross diffusive carbon dioxide and methane emissions from a boreal reservoir and two nearby lakes in Québec, Canada. Biogeosciences 8(1):41-53 
Denfeld BA, Wallin MB, Sahlée E, Sobek S, Kokic J, Chmiel HE, Weyhenmeyer GA (2015) Temporal and spatial carbon dioxide concentration patterns in a small boreal lake in relation to ice cover dynamics. Boreal Environ Res 20:667-678

Denfeld BA, Klaus M, Laudon H, Sponseller RA, Karlsson J (2018) Carbon dioxide and methane dynamics in a small boreal lake during winter and spring melt events. J Geophys Res Biogeosci 123(8):2527-2540

Dinsmore KJ, Billett MF (2008) Continuous measurement and modeling of $\mathrm{CO}_{2}$ losses from a peatland stream during stormflow events. Water Resour Res 44(12):W12417

Dinsmore KJ, Billett MF, Skiba UM, Rees RM, Drewer J, Helfter C (2010) Role of the aquatic pathway in the carbon and greenhouse gas budgets of a peatland catchment. Glob Chang Biol 16(10):2750-2762

Dinsmore KJ, Billett MF, Dyson KE, Harvey F, Thomson AM, Piirainen S, Kortelainen P (2011) Stream water hydrochemistry as an indicator of carbon flow paths in Finnish peatland catchments during a spring snowmelt event. Sci Total Environ 409(22):4858-4867

Dinsmore KJ, Billett MF, Dyson KE (2013a) Temperature and precipitation drive temporal variability in aquatic carbon and GHG concentrations and fluxes in a peatland catchment. Glob Chang Biol 19(7):2133-2148

Dinsmore KJ, Wallin MB, Johnson MS, Billett MF, Bishop K, Pumpanen J, Ojala A (2013b) Contrasting $\mathrm{CO}_{2}$ concentration discharge dynamics in headwater streams: a multicatchment comparison. J Geophys Res Biogeosci 118(2):445-461

Drake TW, Raymond PA, Spencer RGM (2018) Terrestrial carbon inputs to inland waters: a current synthesis of estimates and uncertainty. Limnol Oceanogr Lett 3(3):132-142

Dyson KE, Billett MF, Dinsmore KJ, Harvey F, Thomson AM, Piirainen S, Kortelainen P (2011) Release of aquatic carbon from two peatland catchments in E. Finland during the spring snowmelt period. Biogeochemistry 103(1):125-142

Einarsdottir K, Wallin MB, Sobek S (2017) High terrestrial carbon load via groundwater to a boreal lake dominated by surface water inflow. J Geophys Res Biogeosci 122(1):15-29

Einola E, Rantakari M, Kankaala P, Kortelainen P, Ojala A, Pajunen H, Mäkelä S, Arvola L (2011) Carbon pools and fluxes in a chain of five boreal lakes: a dry and wet year comparison. J Geophys Res Biogeosci 116(G3):G03009

Grabs T, Bishop K, Laudon H, Lyon SW, Seibert J (2012) Riparian zone hydrology and soil water total organic carbon (TOC): implications for spatial variability and upscaling of lateral riparian TOC exports. Biogeosciences 9(10):3901-3916

Gudasz C, Bastviken D, Steger K, Premke K, Sobek S, Tranvik LJ (2010) Temperature-controlled organic carbon mineralization in lake sediments. Nature 466:478

Haei M, Öquist MG, Buffam I, Ågren A, Blomkvist P, Bishop K, Ottosson Löfvenius M, Laudon H (2010) Cold winter soils enhance dissolved organic carbon concentrations in soil and stream water. Res Lett Geophys. https://doi.org/10. 1029/2010GL042821
Hari P, Kulmala M (2005) Station for measuring ecosystematmosphere relations (SMEAR II). Boreal Environ Res 10:315-322

Hari P, Pumpanen J, Huotari J, Kolari P, Grace J, Vesala T, Ojala A (2008) High-frequency measurements of productivity of planktonic algae using rugged nondispersive infrared carbon dioxide probes. Limnol Oceanogr Methods 6(8):347-354

Huotari J, Ojala A, Peltomaa E, Pumpanen J, Hari P, Vesala T (2009) Temporal variations in surface water $\mathrm{CO}_{2}$ concentration in a boreal humic lake based on high-frequency measurements. Boreal Environ Res 14:48-60

Huotari J, Ojala A, Peltomaa E, Nordbo A, Launiainen S, Pumpanen J, Rasilo T, Hari P, Vesala T (2011) Long-term direct $\mathrm{CO}_{2}$ flux measurements over a boreal lake: five years of eddy covariance data. Geophys Res Lett 38(18):L18401

Huotari J, Nykänen H, Forsius M, Arvola L (2013) Effect of catchment characteristics on aquatic carbon export from a Boreal catchment and its importance in regional carbon cycling. Glob Chang Biol 19(12):3607-3620

IPCC (2013) Climate change 2013: The physical science basis. Contribution of working group I to the fifth assessment report of the Intergovernmental Panel on Climate Change. Cambridge University Press, Cambridge, United Kingdom and New York, NY, USA

Ilvesniemi H, Pumpanen J, Duursma R, Hari P, Keronen P, Kolari P, Kulmala M, Mammarella I, Nikinmaa E, Rannik Ü, Pohja T, Siivola E, Vesala T (2010) Water balance of a boreal Scots pine forest. Boreal Environ Res 15:375-396

Jonsson A, Algesten G, Bergström AK, Bishop K, Sobek S, Tranvik LJ, Jansson M (2007) Integrating aquatic carbon fluxes in a Boreal catchment carbon budget. J Hydrol 334(1):141-150

Jungqvist G, Oni SK, Teutschbein C, Futter MN (2014) Effect of climate change on soil temperature in Swedish boreal forests. PLoS ONE 9(4):e93957

Karlsson J, Ask J, Jansson M (2008) Winter respiration of allochthonous and autochthonous organic carbon in a subarctic clear-water lake. Limnol Oceanogr 53(3):948-954

Karlsson J, Giesler R, Persson J, Lundin E (2013) High emission of carbon dioxide and methane during ice thaw in high latitude lakes. Geophys Res Lett 40(6):1123-1127

Kirillin G, Leppäranta M, Terzhevik A, Granin N, Bernhardt J, Engelhardt C, Efremova T, Golosov S, Palshin N, Sherstyankin P, Zdorovennova G, Zdorovennov R (2012) Physics of seasonally ice-covered lakes: a review. Aquat Sci 74(4):659-682

Kling GW, Kipphut GW, Miller MM, O'Brien WJ (2000) Integration of lakes and streams in a landscape perspective: the importance of material processing on spatial patterns and temporal coherence. Freshw Biol 43(3):477-497

Korhonen J, Kuusisto E (2010) Long-term changes in the discharge regime in Finland. Hydrol Res 41(3-4):253

Laudon H, Köhler S, Buffam I (2004) Seasonal TOC export from seven boreal catchments in northern Sweden. Aquat Sci 66(2):223-230

Laudon H, Berggren M, Ågren A, Buffam I, Bishop K, Grabs T, Jansson M, Köhler S (2011) Patterns and dynamics of dissolved organic carbon (DOC) in Boreal streams: the role 
of processes, connectivity, and scaling. Ecosystems 14(6):880-893

Leach JA, Larsson A, Wallin MB, Nilsson MB, Laudon $\mathrm{H}$ (2016) Twelve year interannual and seasonal variability of stream carbon export from a boreal peatland catchment. J Geophys Res Biogeosci 121(7):1851-1866

Ledesma JLJ, Futter MN, Blackburn M, Lidman F, Grabs T, Sponseller RA, Laudon H, Bishop KH, Köhler SJ (2018) Towards an improved conceptualization of riparian zones in boreal forest headwaters. Ecosystems 21(2):297-315

Leith FI, Dinsmore KJ, Wallin MB, Billett MF, Heal KV, Laudon H, Öquist MG, Bishop K (2015) Carbon dioxide transport across the hillslope-riparian-stream continuum in a boreal headwater catchment. Biogeosciences 12(6):1881-1892

Lyon SW, Grabs T, Laudon H, Bishop KH, Seibert J (2011) Variability of groundwater levels and total organic carbon in the riparian zone of a boreal catchment. J Geophys Res Biogeosci 116(G1):G01020

MacIntyre S, Cortés A, Sadro S (2018) Sediment respiration drives circulation and production of $\mathrm{CO}_{2}$ in ice-covered Alaskan arctic lakes. Limnol Oceanogr Lett 3(3):302-310

McAuliffe CC (1971) GC determination of solutes by multiple phase equilibration. Chem Technol 1:46-71

Miettinen H, Pumpanen J, Heiskanen JJ, Aaltonen H, Mammarella I, Ojala A, Levula J, Rantakari M (2015) Towards a more comprehensive understanding of lacustrine greenhouse gas dynamics - two-year measurements of concentrations and fluxes of $\mathrm{CO}_{2}, \mathrm{CH}_{4}$ and $\mathrm{N}_{2} \mathrm{O}$ in a typical boreal lake surrounded by managed forests. Boreal Environ Res 20:75-89

Nyberg L, Stähli M, Mellander P-E, Bishop KH (2001) Soil frost effects on soil water and runoff dynamics along a boreal forest transect: 1. Field investigations. Hydrol Process 15(6):909-926

Ojala A, Bellido JL, Tulonen T, Kankaala P, Huotari J (2011) Carbon gas fluxes from a brown-water and a clear-water lake in the boreal zone during a summer with extreme rain events. Limnol Oceanogr 56(1):61-76

Pasche N, Hofmann H, Bouffard D, Schubert CJ, Lozovik PA, Sobek S (2019) Implications of river intrusion and convective mixing on the spatial and temporal variability of under-ice $\mathrm{CO}_{2}$. Inland Waters 9(2):162-176

Pirinen P, Simola H, Aalto J, Kaukoranta J-P, Karlsson P, Ruuhela R (2012) Climatological statistics of Finland 1981-2010. In: Reports. Finnish Meteorological Institute, Helsinki.

Provenzale M, Ojala A, Heiskanen J, Erkkilä KM, Mammarella I, Hari P, Vesala T (2018) High-frequency productivity estimates for a lake from free-water $\mathrm{CO}_{2}$ concentration measurements. Biogeosciences 15(7):2021-2032

Pumpanen J, Lindén A, Miettinen H, Kolari P, Ilvesniemi H, Mammarella I, Hari P, Nikinmaa E, Heinonsalo J, Bäck J, Ojala A, Berninger F, Vesala T (2014) Precipitation and net ecosystem exchange are the most important drivers of DOC flux in upland boreal catchments. J Geophys Res Biogeosci 119(9):1861-1878
Rantakari M, Kortelainen P (2005) Interannual variation and climatic regulation of the $\mathrm{CO}_{2}$ emission from large boreal lakes. Glob Chang Biol 11(8):1368-1380

Rasilo T (2013) Connecting silvan and lacustrine ecosystems: transport of carbon from forests to adjacent water bodies. In: University of Helsinki, Dissertationes Forestales n:o 155.

Rasilo T, Ojala A, Huotari J, Pumpanen J (2011) Rain induced changes in carbon dioxide concentrations in the soil-lakebrook continuum of a boreal forested catchment. Vadose Zone J. https://doi.org/10.2136/vzj2011.0039

Rasilo T, Ojala A, Huotari J, Starr M, Pumpanen J (2015) Concentrations and quality of DOC along the terrestrialaquatic continuum in a boreal forested catchment. Freshw Sci 34(2):440-455

Striegl RG, Kortelainen P, Chanton Jeffrey P, Wickland Kimberly P, Bugna Glynnis C, Rantakari M (2001) Carbon dioxide partial pressure and ${ }^{13} \mathrm{C}$ content of north temperate and boreal lakes at spring ice melt. Limnol Oceanogr 46(4):941-945

Teodoru CR, del Giorgio PA, Prairie YT, Camire M (2009) Patterns in $\mathrm{pCO}_{2}$ in boreal streams and rivers of northern Quebec, Canada. Glob Biogeochem Cycle 23(2):GB2012.

Tiwari T, Sponseller RA, Laudon H (2018) Extreme climate effects on dissolved organic carbon concentrations during snowmelt. J Geophys Res Biogeosci 123(4):1277-1288

Vachon D, Prairie Y, Guillemette F, del Giorgio PA, (2016) Modeling allochthonous dissolved organic carbon mineralization under variable hydrologic regimes in boreal lakes. Ecosystems 20(4):781-795

Vachon D, Solomon CT, del Giorgio PA (2017) Reconstructing the seasonal dynamics and relative contribution of the major processes sustaining $\mathrm{CO}_{2}$ emissions in northern lakes. Limnol Oceanogr 62(2):706-722

Veijalainen N, Lotsari E, Alho P, Vehviläinen B, Käyhkö J (2010) National scale assessment of climate change impacts on flooding in Finland. J Hydrol 391(3):333-350

Verpoorter C, Kutser T, Seekell DA, Tranvik LJ (2014) A global inventory of lakes based on high-resolution satellite imagery. Geophys Res Lett 41(18):6396-6402

Wallin MB, Weyhenmeyer GA, Bastviken D, Chmiel HE, Peter S, Sobek S, Klemedtsson L (2015) Temporal control on concentration, character, and export of dissolved organic carbon in two hemiboreal headwater streams draining contrasting catchments. J Geophys Res Biogeosci 120(5):832-846

Zarnetske JP, Bouda M, Abbott BW, Saiers J, Raymond PA (2018) Generality of hydrologic transport limitation of watershed organic carbon flux across ecoregions of the United States. Geophys. Res. Lett. 45(21):11702-711711

Publisher's Note Springer Nature remains neutral with regard to jurisdictional claims in published maps and institutional affiliations. 